\title{
Reliability of first-hand accounts on the study of historical tsunamis in northeastern Venezuela (southeastern Caribbean Sea)
}

\author{
Franck A. Audemard M. ${ }^{1 *}$ and Alejandra F. Leal Guzmán ${ }^{1}$ \\ ${ }^{1}$ Earth Sciences Dpt., Venezuelan Foundation for Seismological Research -FUNVISIS-, Caracas, Venezuela
}

Article history

Received April 29, 2017; accepted July 29, 2017.

Subject classification:

Tsunami hazard; Inundation; Run-up; Strike-slip faults; Sliding; Caribbean.

\begin{abstract}
The occurrence of tsunami waves on the eastern Caribbean Venezuelan coasts during 5 Venezuelan (local) earthquakes (01-IX-1530, 15-VII1853, 29-X-1900, 17-I-1929 and 9-VII-1997), have been confirmed through the search and evaluation of written accounts by primary sources (eye witnesses) of tsunami inundation during these events. Among the outcomes of this new assessment are: 1) the run-up heights of several of those tsunamis have been substantially reduced. In fact, maximum run-up heights for the 5 tsunamis are: 5-7 mat Cumaná for the 1530 event, $5 \mathrm{~m}$ at Barlovento and $3 \mathrm{~m}$ at the Neveri mouth for the 1900 tsunami, 3 m at western Cumana for the 1853 and 1929 events and about $1 \mathrm{~m}$ for the 1997 earthquake. 2) These new estimates on wave heights for local earthquakes restrict the search for tsunamites by trenching and coring to mainly the first 500-m-wide strip from the coastline in low-lying flatlands. The source of these tsunami waves may be complex. Some are the result of coastal-submarine sliding (1929 AD, 1997 AD), tectonic slip on active strike-slip (or normal oblique slip) faults (1530 AD, $1900 \mathrm{AD}$ ) or combination of tectonic slip and sliding (1853 AD). Appropriate numerical modeling of tsunami wave generation, migration and inundation are urgently in need to understand these tsunami mechanics.
\end{abstract}

\section{Introduction}

The 1983 National Inventory of Geologic Hazards [Singer et al. 1983] and the 1999 Catalog of Felt/Destructive Venezuelan Earthquakes (1530-1998); [Grases et al. 1999] reliably report the occurrence of tsunami waves on the Caribbean Venezuelan coasts, or phenomena that might be interpreted as substantial sea level modifications in the region, during local, regional and extra-regional earthquakes, as well as related to other natural phenomena. In this research, we narrow down the focus of this investigation in 4 ways: 1) the tsunami source is an earthquake (tsunamigenic earthquake); 2) the earthquake has happened on a local (Venezuelan) tectonic source; 3 ) Eyewitness (first-hand) accounts provide characteristics (actual occurrence, location, time, inundation height, run-up and so on) of the tsunami; and 4) the tsunamis must have affected the eastern coasts of Venezuela. The last constraint responds to the area objective of Project FONACIT 2013000361, which funds the current research. This geographical constraint answers to the potential favorable conditions of preservation of tsunamites along the low-lying coasts of the Ensenada de Barcelona (Barcelona Embayment; from Cabo Codera to Araya) envisaged from the early stages of this investigation, as already proven by few pioneering tsunamite studies [Leal and Scremin 2011, Audemard 2012, 2014, Oropeza et al. 2013 2015, Leal et al. 2014], where most tsunami affectation in Venezuela in last centuries is reported in both abovementioned catalogs (inventories) [Audemard and Leal 2012, 2013, 2014, 2015]. In such research project, search of tsunamite by short (over a $1 \mathrm{~m}$ long) coring and shallow-pit hand digging is the geologic approach implemented to corroborate the occurrence of past tsunamis in association with its local tsunamigenic source. Last but not least, the use of firsthand accounts seeks to optimizing reliability on occurrence and characteristics of individual tsunamis. This research then is mainly substantiated by a documentary assessment, which also includes last century pertinent photographs to contextualize the event in time and space, all supported with fieldwork observations on topography, coastal geomorphology, river morphology and hydrology, geological and natural coastal environments, and anthropogenic (cultural) aspects. All this is carried out as to recreate the prevailing conditions at the time of occurrence of each of the 5 events, to which we would apply the ITIS 2012 [Lekkas et al. 2013] and Imamura-Iida magnitude scale [Iida, 1963]. 


\section{Offshore active faults of Venezuela}

Northeastern Venezuela at present is the most seismically active area nationwide, as documented by the instrumental seismicity catalog of the Venezuelan Foundation for Seismological Research -FUNVISIS- for the period 1910-present (www.funvisis.gob.ve). In historical times, the seismic activity was not much different, as indicated by historical reports on damage in this region by earthquakes and tsunamis from the dawn of the Spanish conquest [Centeno-Graü 1940, 1969, Gómez 1990, Grases 1990, Grases et al. 1999]. Such colonization started at the beginning of the $16^{\text {th }}$ century with Nueva Toledo in 1515, known today as Cumaná -the oldest Spanish settlement on continental America-. In fact, this city has been repeatedly destroyed to some extent during historical earthquakes [Audemard 2007], such as in $1530,1629,1684,1766,1797$ and 1853 , as well as during two events in the $20^{\text {th }}$ century (1929 and 1997).

All these events have been associated by different authors to the El Pilar fault (EPF) that is considered to be the second major seismic source in eastern Venezuela after the southern end of the NW-dipping slab of the Lesser Antilles Subduction zone that lies under Trinidad and partly under the Paria Gulf and Peninsula (Figure 1). The EPF, along with the right-lateral strike-slip Boconó and San Sebastián faults, appears to accommodate a large fraction of the dextral transcurrent motion (Figure 1); [Molnar and Sykes 1969, Minster and Jordan 1978, Pérez and Aggarwal 1981, Stephan 1982, Aggarwal 1983, Schubert 1984, Soulas 1986, Beltrán and Giraldo 1989, Speed et al. 1991, Singer and Audemard 1997, Pérez et al. 2001, Weber et al. 2001, Audemard and Audemard 2002, Audemard et al. 2005, Audemard 2006, Jouanne et al. 2011, Reinoza et al. 2015, among many others] within the over a 100$\mathrm{km}$-wide transcurrent-compressive plate-boundary zone between the Caribbean and South America plates. It is worth mentioning that the EPF active fault trace to which this paper refers, corresponds to the fault mapped by Beltrán et al. [1996]. This mapping is more easily accessible from Audemard et al. [2000; Figure 2]. Audemard [1999, 2007, 2011], Altez and Audemard [2008] and Audemard et al. [2007] have associated most of the offshore historical destructive earthquakes in eastern Venezuela (1530, 1629, 1684, 1797, 1853, 1929 and 1997) with EPF. Moreover, each of these events has been associated with a particular segment of the fault. For instance, the Mw 6+ earthquakes of 1629 [Altez and Audemard 2008] and 1797 and 1929 [Audemard 1999, 2007, Audemard et al. 2007] have all broken inside the Cariaco Gulf, just east of Cumaná. Except for the 1929 event, they seem not to have generated tsunami waves in the Cariaco Gulf, which has significant implications on the source mechanism for the 1929 tsunami waves. Likewise, the 1812 and 1900 large offshore earthquakes in North-Central Venezuela have been associated to segments of the San Sebastián fault (SSF), [Audemard 2002, Colón et al. 2015].

\section{Tsunamigenic earthquakes}

From a recent chronology of tsunami reports in Venezuela compiled by Oropeza and Audemard [2016] from published data, which essentially gathers only tsunami data from 6 catalogs [Centeno-Graü 1940, Singer et al. 1983, Grases 1990, Grases et al. 1999, O'Loughlin and Lander 2003, Altez and Rodríguez 2009] and a published paper [Schubert 1987], just five local earthquakes out of 24 events with clear reports of sea surface perturbations, have affected the Eastern Venezuela coasts, which are, in sequence: 1-IX-1530, 15VII-1853, 29-X-1900, 17-I-1929 and 9-VII-1997 (Figure 3). Although the 1766 event is the largest earthquake in Eastern Venezuela, it has dubious evidence of tsunamis; probably related to the fact that it is an intermediate depth event [Audemard 2007, Mocquet

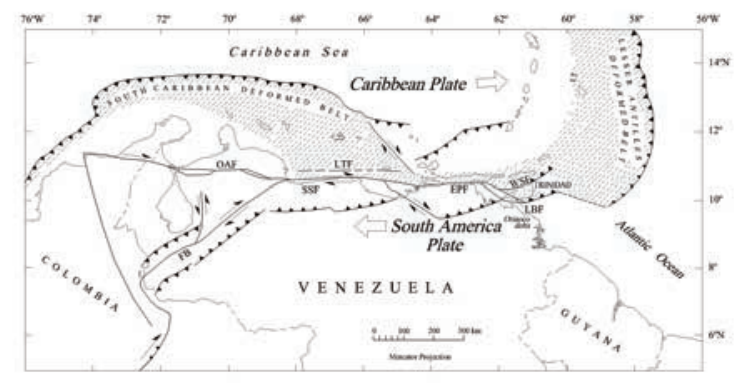

Figure 1. Simplified geodynamic framework of Northern South America (from Audemard et al. 2000]. Abbreviations: BF Boconó fault; EPF El Pilar fault; LBF Los Bajos-El Soldado fault system; OAF Oca-Ancón fault system; SSF San Sebastián fault.

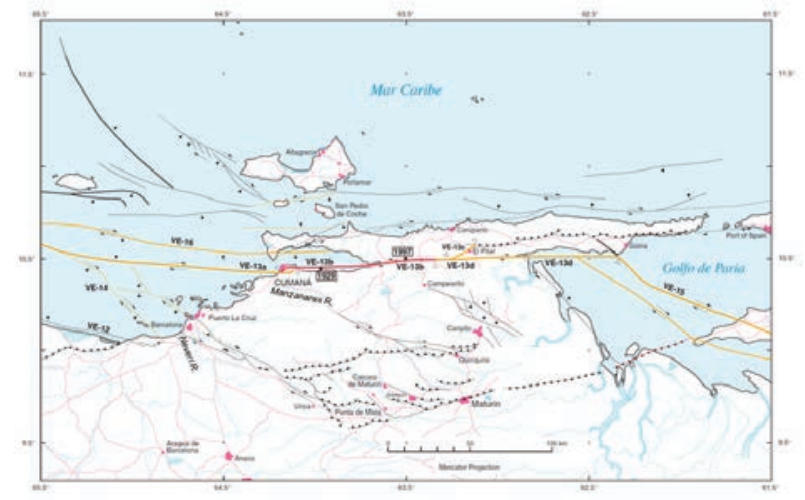

Figure 2. Quaternary fault map of northeastern Venezuela [after Audemard et al. 2000]. VE-13 identifies the El Pilar fault (EPF) and the suffixes (a through d) label the different individual fault portions or segments. Epicenters of the 1929 and 1997 earthquakes are shown as solid circles. Faults in red have had fault surface ruptures, or portions of it, mapped. 


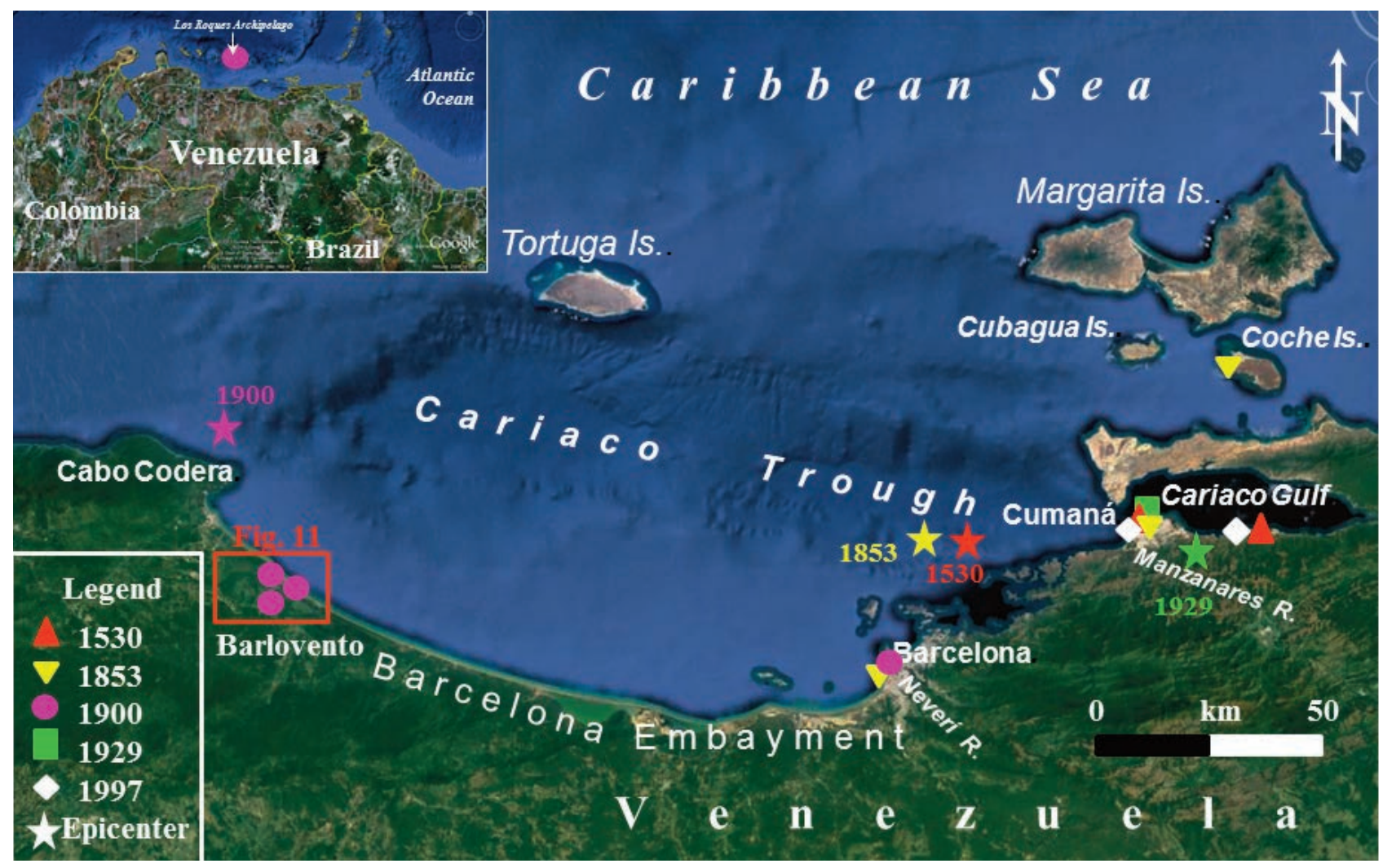

Figure 3. Map of eastern Venezuela extracted from Google Earth showing the different localities with confident eye-witness reports of tsunami inundations, or sea surface oscillations, during local historical and instrumental earthquakes. Epicenters of historical and 1929 earthquakes are indicated by stars, whose epicentral coordinates are provided in Table 1. Relative location of Figure 11 is also depicted.

2007]. All but the 1900 event, whose several proposals of epicenter locations all lies in North-Central Venezuela, have been generated by the EPF. Instead, the 1812 tsunami, also generated by the San Sebastían fault (SSF) offshore North-Central Venezuela, is not herein treated, because its hypocenter lies too far west and seems not have affected Eastern Venezuela. The $1900 \mathrm{AD}$ event is the second largest earthquake (Ms 7.6) [Pacheco and Sykes 1992] in magnitude in the Venezuelan seismic catalog, after the 1766 event (Mw 7.8), whose felt area is twice as large as the surface of the entire country, but the $1900 \mathrm{AD}$ event is the largest earthquake of all times at crustal depth. All five tsunamigenic earthquakes are considered to be crustal events [e.g., Audemard 2007, Colón et al. 2015].

The $1900 \mathrm{AD}$ tsunami waves were reported along most of the Ensenada de Barcelona coast (Barcelona Embayment, W of Cumaná) and Los Roques Archipelago (Figure 3 and inset), being this quake attributed to the SSF segment running offshore Cabo Codera by Colón et al. [2015], based on fresh seafloor scarps detected by high resolution shallow reflection seismics in 2007. After Audemard [1999, 2007], the 1530 and 1853 earthquakes were produced by the Cariaco Trough segment of the EPF west of Cumaná, within a restricted over-1000-m-deep marine pull-apart basin on the SSF-EPF right-lateral releasing step-over (Figures 2 and 3), whereas the 1929 and 1997 events occurred on the EPF segment east of Cumaná, inside the $<100-\mathrm{m}$ deep Cariaco Gulf (Figure 2). Several authors have interpreted all those four tsunamis as the result of major submarine sliding inside the steep-walled trough. Firsthand accounts by locals about the abnormal waves during the Cariaco 1997 event, as well as the identification of coastal sliding at the Manzanares River mouth at Cumaná [González et al. 2004], support this hypothesis at least for the two latest events, because of the small size of the tsunami-affected area (Figure 3). In addition, recent seafloor monitoring [CARIACO Project; e.g., Thunell et al. 1999, Lorenzoni et al. 2012] has recorded turbidite currents in the Cariaco Trough and the Manzanares Canyon -the latter connecting the Manzanares River mouth to the eastern deep basin of the Cariaco Trough-, during the Cariaco Mw 6.9 earthquake, and also with a smaller, Mw. 5.2, August 2008 event. However, the 1900 tsunami, and the 1530 and 1853 tsunamis by extension, appears to result from right-lateral tectonic slip along the Cariaco Trough walls [Audemard and Leal 2012, 2013]. However, Aguilar et al. [2016], in order to explain an improved water exchange between the Cariaco Gulf and open sea since around $1850 \mathrm{AD}$, which has made the gulf waters more salty in more recent times, propose that the submarine Salazar Sill slid during the 1853 earthquake, thus deepening and en- 
larging the gulf entrance north of Cumaná, and increasing open sea water inflow. In such a case, the tsunami waves during this event could have resulted from an enhanced combination of tectonic slip and submarine sliding.

\section{Description of historical tsunamis from first-hand accounts}

As mentioned earlier, this study intends to explore how first-hand or eyewitness accounts can be used to better constraining tsunami inundation and tsunami height and run-up elevation for the five earthquakes that are known from earthquake (and/or tsunami) catalogs to have inundated a locality or several of them along the Barcelona Embayment coasts. To do this, we have started this assessment by looking into the most recent historical event (the January $17^{\text {th }}, 1929$ earthquake) that should logically have the largest number of and more detailed accounts, which happens to be the case.

\subsection{The January $17^{\text {th }}, 1929$ tsunami}

For this earthquake, the occurrence of tsunami waves at the city of Cumaná is repeatedly reported. For instance, Centeno Graü [1940] indicates: "El mar se retiró de la playa como 200 mts y vino después a la costa una ola como de 6 metros de altura que barrió parte de las casas de la playa." (The sea retreated some $200 \mathrm{~m}$ and came back to shore as a $6 \mathrm{~m}$ high wave that washed down houses on the beach; Free translation by authors -FTBA-). Paige [1930] reports "A tidal wave followed the earthquake causing much damage." The front page of the Caracas newspaper La Esfera on January $19^{\text {th }} 1929$ says “...embarcaciones de caleta que se encontraba en el muelle de Puerto Sucre fueron alejados al mar; éste, embravecido, lanzó sus aguas hacia la población, en sentido inverso a una tromba de lo que envolvió completamente al "Commewynne" y otras embarcaciones, de las cuales algunas naufragaron. El mencionado vapor holandés se vio juguete de olas y sólo, gracias a la entereza de su capitán que ordenó hábiles maniobras, a posibles contingencias". The FTBA is as follows: "Anchored boats at Puerto Sucre -Cumaná seaport- were pulled offshore; the sea returned with strong surfs to the village, wrapping completely the steam vessel Commewynne and other boats, of which some sunk. The Dutch steam vessel (Figure 4) seemed like a toy and only skillful manoeuveurs of its capitain saved it". This is confirmed by another Caracas newspaper on the same day January 19 (El Nuevo Diario), which expresses “...en Puerto Sucre, donde los daños fueron menores, hubo un violento mar de eleva. El vapor holandés por esta causa, tuvo que retirarse varias veces hacia alta mar, volviendo luego a la Costa. ....Los botes amarrados al costado del muelle se anegaron por completo." The translation goes: "In Puerto Sucre (Figures 5 and 6), where damage was minor, there was a violent tsunami wave. The Dutch steamboat, due to the tsunami waves, had to sail to open sea several times, later returning to shore.... Boats tied to the pier sides were completely drowned". Three days later, the same newspaper publishes the following: "Dos detalles impresionantes del terremoto fueron el desbordamiento del río Manzanares, que en su curso atraviesa la ciudad, cuyas aguas arrastraron cuanto encontraron a su paso, causando enormes daños. Fue el otro la invasión del mar que, elevándose en una marejada de nueve pies sobre su nivel ordinario, se lanzó sobre "El Salado", inundándolo totalmente. Este caserío sufrió considerablemente. La mayoría

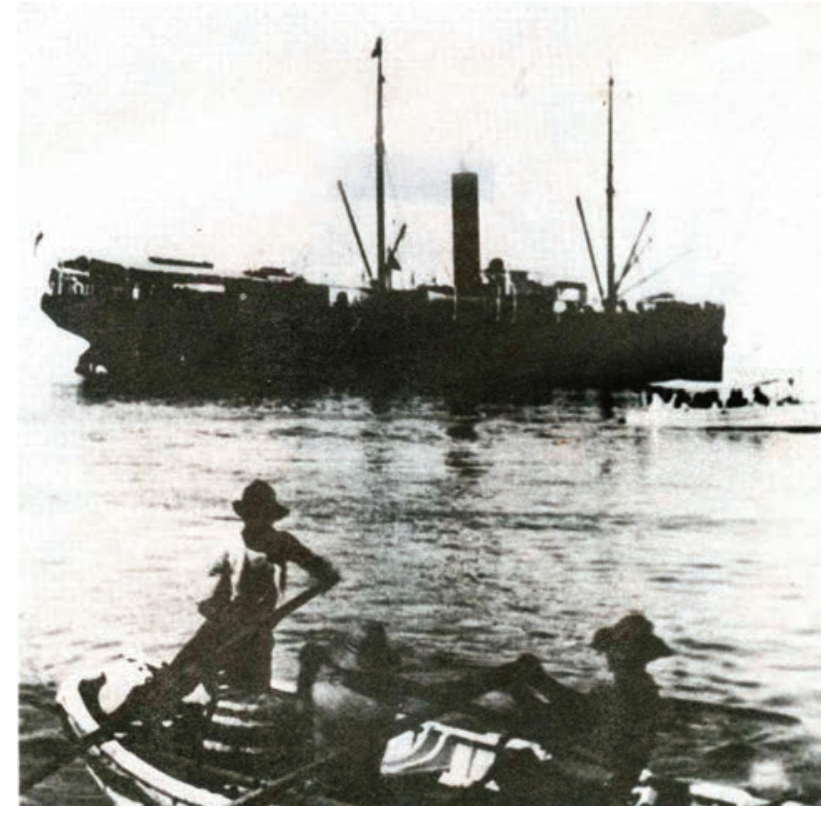

Figure 4. Typical Dutch vessel, named El Holandés, that came to Pto Sucre seaport, Cumaná, in the first half of the $20^{\text {th }}$ Century (Anonymous photographer).

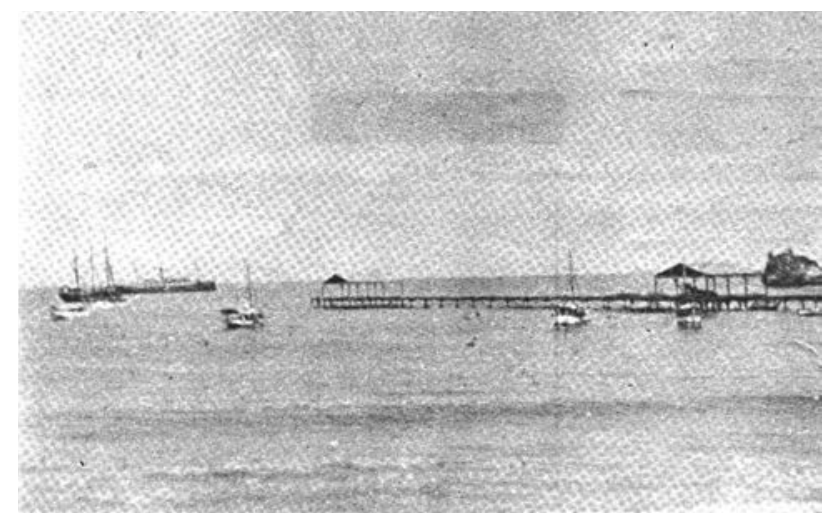

Figure 5. Ground view of the Puerto Sucre seaport, Cumaná, in 1925, 4 years before the 1929 earthquake. The wooden pier and shelter structures appear rather slim. In the far background, a typical steam boat of the time is anchored, as well as a sailing boat of the sloop type. On the foreground, "piragua" type boats, which are much different from the freshwater canoe or pirogue boats carved by Indians into a single trunk. 


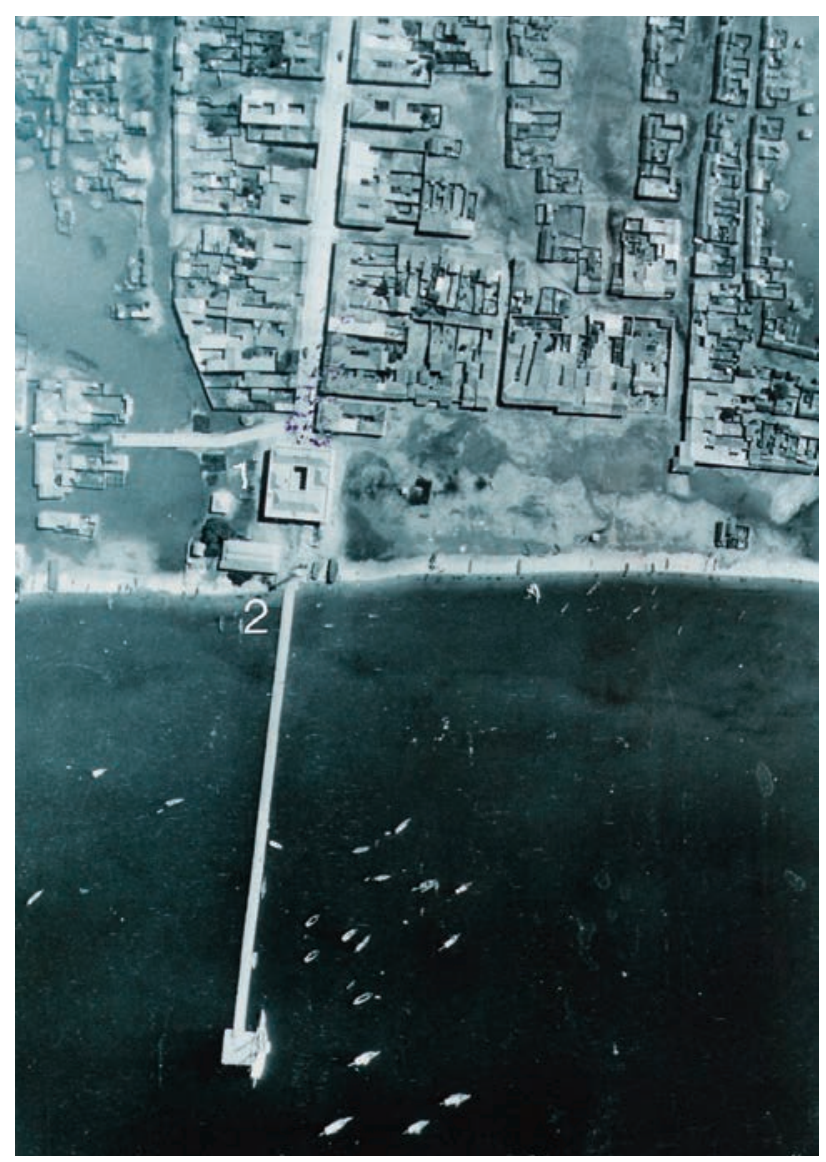

Figure 6. Aerial photograph of the seaport of Cumaná, known as Puerto Sucre, after the 1929 earthquake, during the phase of reconstruction and upgrading in the 1930. In this view, the narrow lightcolored coastal sand barrier is easily recognizable along seashore. In the same way, the salt flats, of lower elevation than the barrier, are identifiable because of being flooded, particularly in the upper left corner of the picture. From the size, the boats appear to be "piraguas", except for the large sloop tied to the pier. Instead, some "peñeros" (small wooden rowing fisherman boats) lie on the beach.

de sus viviendas, todas gente pobre y trabajadora, quedaron casi destruidas." (Two impressive facts of the earthquake were the overflowing of the Manzanares River that crosses the city, whose waters destroyed everything, causing much damage. And the other was the sea invasion, which with an abnormal height of 9 feet struck El Salado -a small fishermen settlement on the southern bank of the Manzanares mouth (Figure 7); now being part of Cumaná-, flooding it completely. This settlement suffered considerably. Most of the dwellings, belonging to poor and labor people, were almost destroyed -FTBA-). The same newspaper on March 03, several weeks after the earthquake and tsunami, says: "El mar por un momento se retiró para luego tornar formando una extensa marejada de gran elevación, que inundó la población situada en el puerto.... El Río hinchó violentamente sus ondas que se llevaron por delante cuanto a su paso encontraron". Translated into English: "The sea for a short spell retreated to return later as a tsunami wave of big height..... The river swelled violently de- stroying everything at its passage". The last first-hand account we could find appeared on the nationwide newspaper El Universal on March 22, 1929. It indicates “...en el preciso momento de la catástrofe algunos pescadores cuyas barcas estaban ancladas en Puerto Sucre vieron amenazante hacia el Norte franco una negra y formidable nube que se levanta sobre las aguas del mar, y que creyendo fuera una borrasca o chubasco marino dieron la voz de alarma es decir, de amarrar o de asegurar sus embarcaciones, de la cual no tuvieron tiempo, pues al instante estalló el cataclismo y una ola colosal los arrojo con sus barcos sobre la playa" (...right at the moment of the catastrophe, some fishermen, whose boats were anchored at Puerto Sucre (Figures 4 through 6 and 8), saw an amazing and black threatening cloud rising over the sea due North, and believing it was a storm, gave the alarm of fastening and securing the boats, but in such a short notice and having not enough time, a colossal wave rafted the boats ashore).

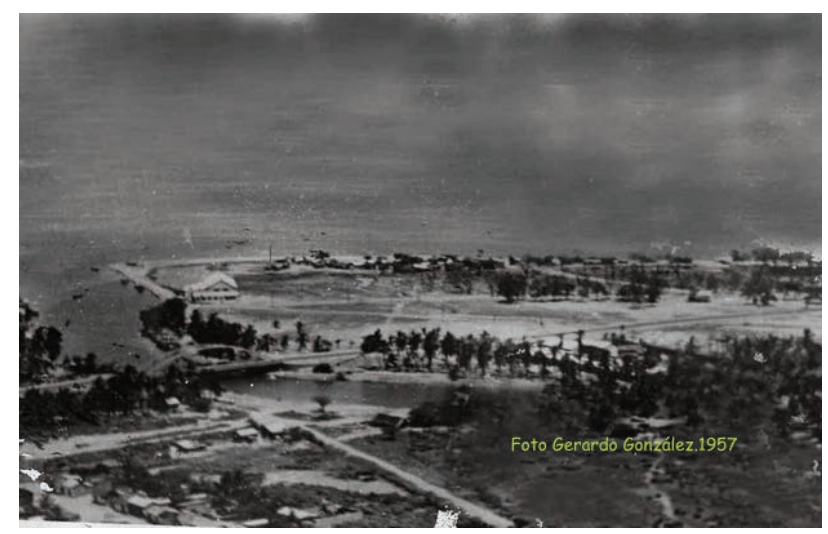

Figure 7. NW-looking bird-eye view of the Manzanares River mouth, in 1957, embanked on both sides. River width close to the mouth is in the order of some $50 \mathrm{~m}$. On the right (northern bank) used to sit the Francis Rodel fish cannery, in the El Dique neighborhood. On the southern bank has developed the El Salado neighborhood; largely affected by most tsunamis that has struck Cumaná through the years. The steel bridge, which used to exist during the first author's youth, was named Aristides Rojas. Coconut tree plantations are visible along the river margins. Photograph by Gerardo González.

These several accounts provide very useful information for the understanding of what precisely happened during the January $17^{\text {th }}, 1929$ earthquake and tsunami that struck Cumaná, and particularly its western coast, extending between the Manzanares River mouth to the North and the city port named Puerto Sucre to the South, and affecting the fishermen village of the El Salado sitting on that coast stretch. It is worth noting that this western coast stretch of Cumaná, although in a partly-protected large embayment opened to sea towards the West, is more exposed to open sea; reason why the seaport sits there. Being this city well 


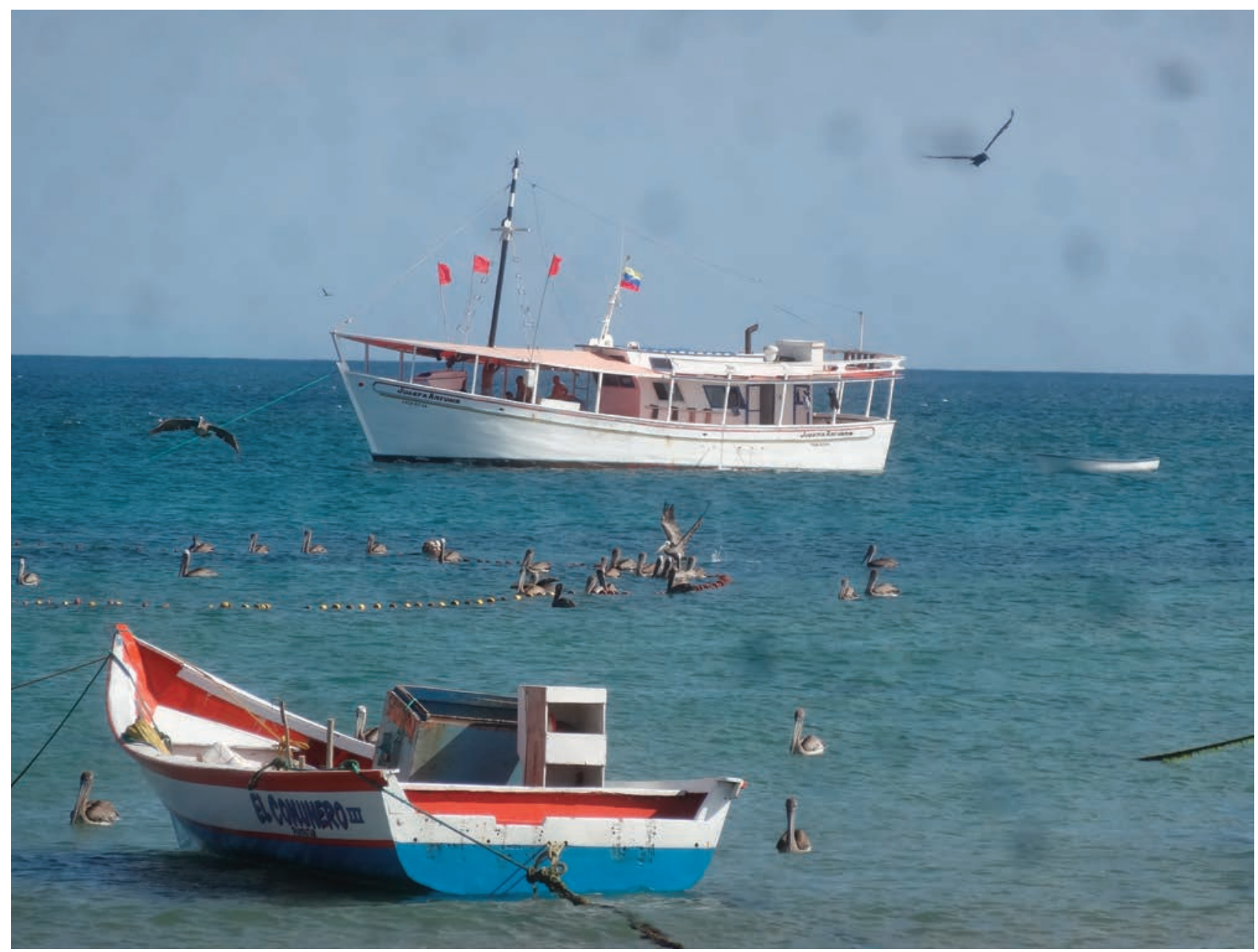

Figure 8. Modern equivalents to the boats that could have been tied to the Puerto Sucre pier in 1929: "Piragua" in the far background and "Peñero" in the foreground.

known to the first author, this allows describing the preevent scenario rather profusely. The city of Cumaná has grown on a salt-flat (Figure 9) that had to be progressively artificially filled to be constructed and urbanized through the years. Cumaná suffered from inundation after every single large rain or pour (Figure 10). This situation was later overcome with the construction of the city drainage system in the 70's, accompanied by the design and construction of a spillway for the Manzanares River. The salt-flat originally formed behind a coastal sand barrier that hardly reaches $1.7-2.0 \mathrm{~m}$ amsl in elevation, and the salt flat floor used to be close to a $1 \mathrm{~m}$ below msl (Figures 9 and 10a). Salt exploitation by locals was still a common practice in 1960 's. It also implies that tsunami wave height and inundation height (flow depth) or run-up height at Cumaná is about the same. It is of major importance to indicate that tidal range along the Venezuelan coast is less than $35 \mathrm{~cm}$. Therefore, time of tsunami with respect to tide height plays almost no role on the inundation height. In terms of typical navigation vessels, it is relevant to mention that fishermen in northeastern Venezuela in the first half of the $20^{\text {th }}$ century most frequently used "Piragua" boats that are 6 to $10 \mathrm{~m}$ long and have a draught between 1 and $2 \mathrm{~m}$ depending on the load aboard, which are still in use by present-day fishermen (Figures 5 and 8).

From all these accounts, the tsunami wave height retained by most scientists is the one from Centeno Graü [1940] of $6 \mathrm{~m}$. It is the most straightforward and no interpretation is needed. But we have to bear in mind that Centeno Graü's work is a catalog in itself; in other words, the result of a compilation and not a first-hand account. However, this value can be in some way tested, and even contested. As a matter of fact, another account indicates only 9 feet high waves (some $3 \mathrm{~m}$; El Nuevo Diario of January $\left.22^{\text {nd }}, 1929\right)$. Another estimate of the wave height can be derived from the following facts: A) The anchored boats at Puerto Sucre (probably of the Piragua type; Figures 5, 6 and 8) were rafted ashore by the waves; being these boats no more than $3 \mathrm{~m}$ deep and exhibiting draughts between 1 and $2 \mathrm{~m}$, and taking into account that the coastal sand barrier is about $1.5 \mathrm{~m}$ high, to abandon the boats at the shore, as mentioned in the account, the tsunami waves were hardly over $3 \mathrm{~m}$ in height. If run-up height had been larger, the boats would have been abandoned much farther inland. B) 
The fact that the "Commewynne" steam-boat at Puerto Sucre could sail out to sea repeatedly, it implies that the captain had time to respond to arriving tsunami waves, which were not large and powerful enough to drift the ship ashore. C) Several boats tied to the pier drowned. If these boats also are of the Piragua type

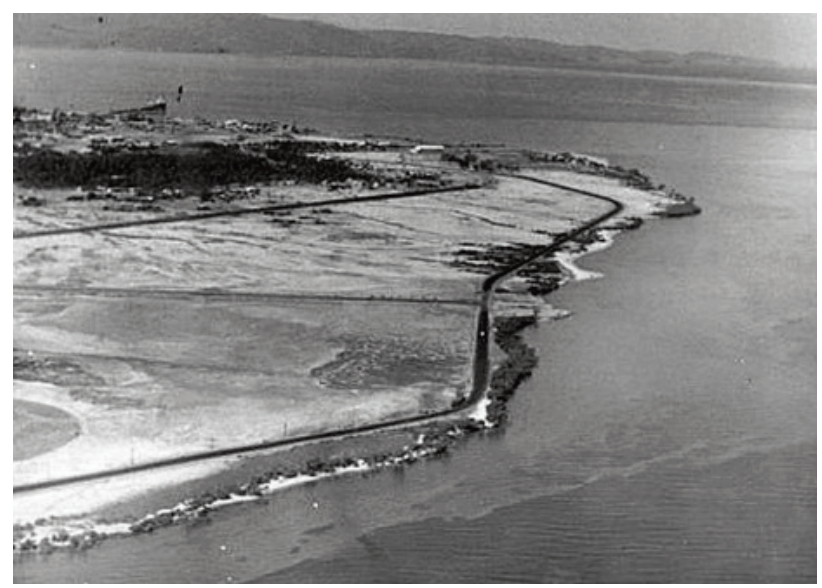

Figure 9. Bird-eye view to the west of Cumaná in 1950, showing $T$ intersection between Los Mangles (future Perimetral) and Fernández de Zerpa avenues. In the foreground, notice salt deposition. Puerto Sucre seaport is visible above the trees. In the far background, the shape outline of the relief of the Eastern Interior Range stands out.

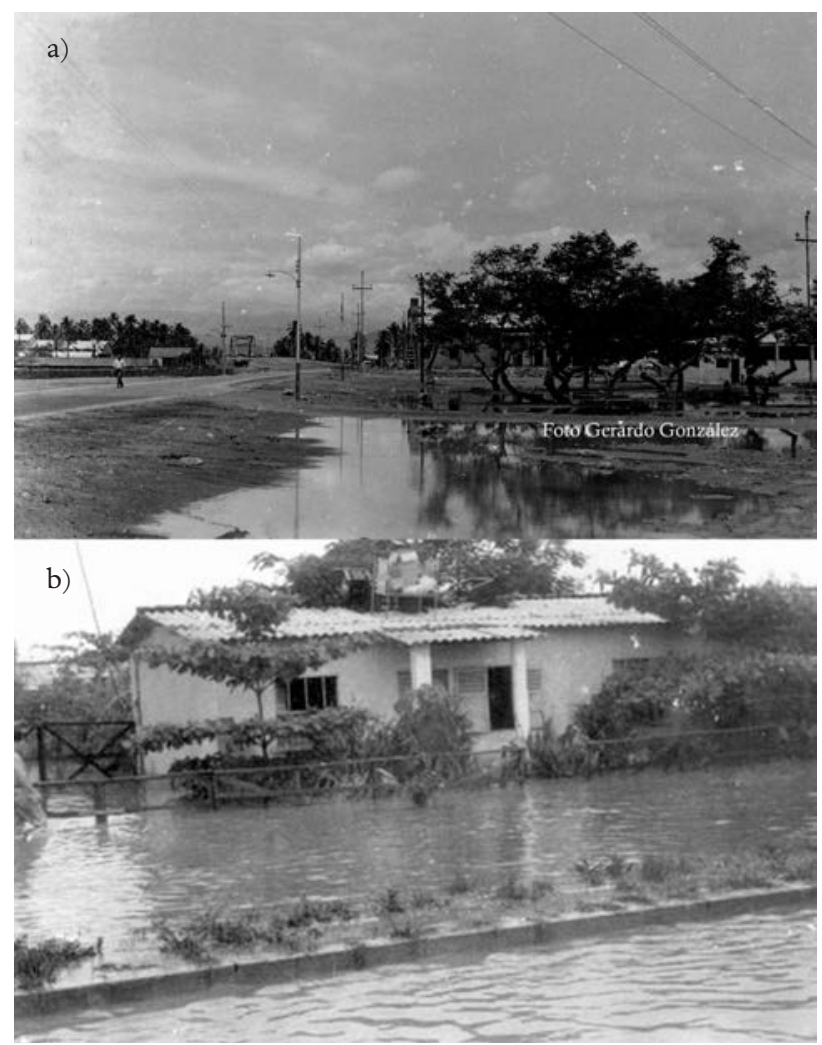

(Figures 5, 6 and 8), a 2-3 $\mathrm{m}$ high wave would be largely enough to sink boat that could not freely float. And D) The sea along the west coast of Cumaná, whose seabottom is very flat, retreated some $200 \mathrm{~m}$ before returning and overflowing the sandy beach. If this is compared to the first author's observations collected during the 1997 event [González et al. 2004], a sea retreat along the same stretch of beach of a $100 \mathrm{~m}$, allowed estimating a wave height in the order of a $1 \mathrm{~m}$. By analogy, at constant beach slope gradient, the retreat of some $200 \mathrm{~m}$ during the 1929 tsunami would be equivalent to a wave of a couple of meters at most.

From these observations several other conclusions can be drawn: 1) several waves seem to have happened. 2) Most eyewitnesses at Cumaná first report a sea retreat, like for the 1997 earthquake. 3) The tsunami wave are reported on the west coast of Cumaná, on the open seaside, completely opposed to the earthquake epicenter proposed by Mocquet et al. [1996] and Audemard [1999, 2007],(Figures 2 and 3), which lies inside the Cariaco Gulf. Therefore, it should be considered that this tsunami is necessarily related to a submarine slump or slide occurring in the Cariaco Trough, and probably inside the submarine Man-

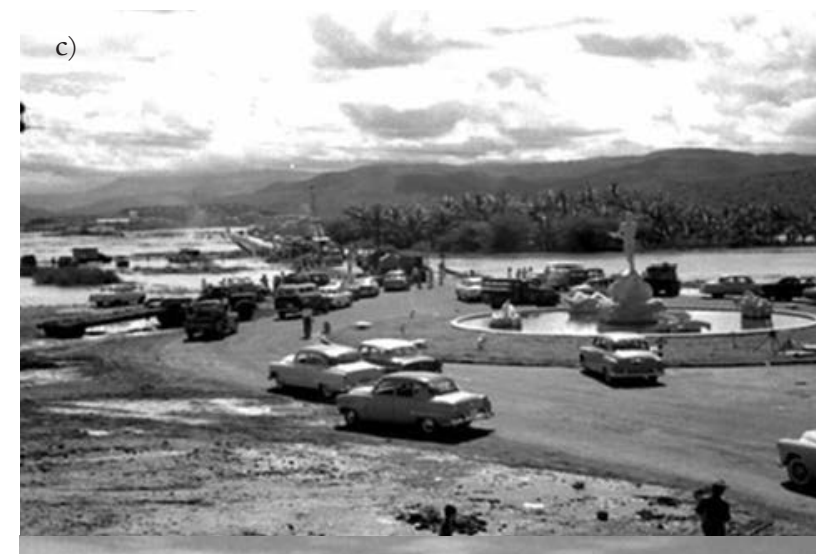

d)

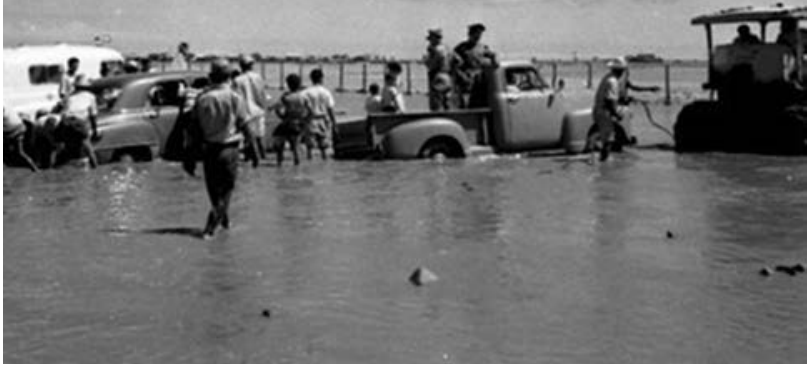

Figure 10. Cumaná, a city prone to past flooding. a) View to south of the future Perimetral Avenue, at El Dique in 1960, with Aristides Rojas bridge over the Manzanares River in background. Small ponds attest to recent rains. Note typical vegetation: coconut trees on the riversides and mangrove trees in the foreground (Picture by Gerardo González). b) Cancamure Avenue flooded after heavy rain. c) All flooded around the El Indio roundabout in the 1960's (Picture by Vitorio De Benedetto). d) Las Palomas sector, upstream of the Aristides Rojas bridge, inundated by Manzanares River overflow in 1960's (Picture by Vitorio De Benedetto). These flooding problems were minimized with the construction of a diversion channel, pouring to the east into the Cariaco Gulf in the 1970's. 
zanares Canyon, in a similar way to the tsunami wave reported during the 1997 earthquake, which shows evidence of subaerial sliding at the Manzanares river mouth [González et al. 2004], whose turbidite currents into the Cariaco Trough were reported by Thunell et al. [1999] and Lorenzoni et al. [2012]. And 4) Two firsthand accounts (El Nuevo Diario on 1929/I/22 and 1929/III/03) report the rise of the Manzanares River waters along its final stretch, overbanking and flooding along the river course. This seems to point out to generation of a riverbore at the river mouth.

Applying the ITIS-2012 tsunami intensity scale proposed by Lekkas et al. [2013], the western coast of Cumaná, stretching from Puerto Sucre to the Manzanares River mouth, can be classified as intensity VII (damaging) to VIII (heavily damaging), based on boats drifted ashore and damage grade 4 to dwellings of high vulnerability (classes A and B), respectively. Using the same level of damage, according to Imamura-Iida magnitude scale [Iida, 1963], this tsunami should be graded 1, to which would correspond a wave height range of 2 to $5 \mathrm{~m}$, which appears to be consistent to one of the eye-witness accounts, as well as to our evaluation. ITIS-2012 also indicates that tsunami wave for intensity VIII is expected to be higher than $2 \mathrm{~m}$, but smaller than $5 \mathrm{~m}$ (corresponding to intensity IX).

\subsection{The October $29^{\text {th }}, 1900$ tsunami}

For the October $29^{\text {th }}, 1900$ earthquake-tsunami, the first-hand accounts tell us a similar story. The newspaper la Linterna Mágica, on November the $2^{\text {nd }}$, publishes: "En el Puerto Tuy el mar se separó como ocho cuadras, y luego se vino encima de la playa una gran mole de agua como de diez metros de altura que anegó los almacenes." (At Puerto Tuy (Figure 11), sea retreated like 8 "cuadras" -about $1 \mathrm{~km}$; a "block" ranges between 100 a $150 \mathrm{~m}$ in length-, and then returned onto the beach as a huge wall of water of about $10 \mathrm{~m}$ high, which flooded the warehouses -FTBA-). Another account in the same newspaper indicates that: "Una parte del pueblo de Paparo se hundió en el agua, quedando las casas sólo con la mitad afuera." (A portion of the village of Paparo (located next to seashore; Figure 11) was drowned, being only the upper half of the houses sticking out -FTBA-). On La Religion of November $6^{\text {th }}$, the following note was found: "En San José, población situada a menos de dos millas de Río Chico, se desbordó el río que atraviesa el pueblo en ambas márgenes, bañando las calles y luego se volvió a su cauce natural, siendo más grave este fenómeno cuanto que una de las márgenes del río San José tiene cuatro metros de altura. El mismo fenómeno se verificó en todo el curso del río, brotando a tierra un sinnúmero de peces que sirvieron de alimento a la población en aquellos instantes de pavor; $y$ de di-

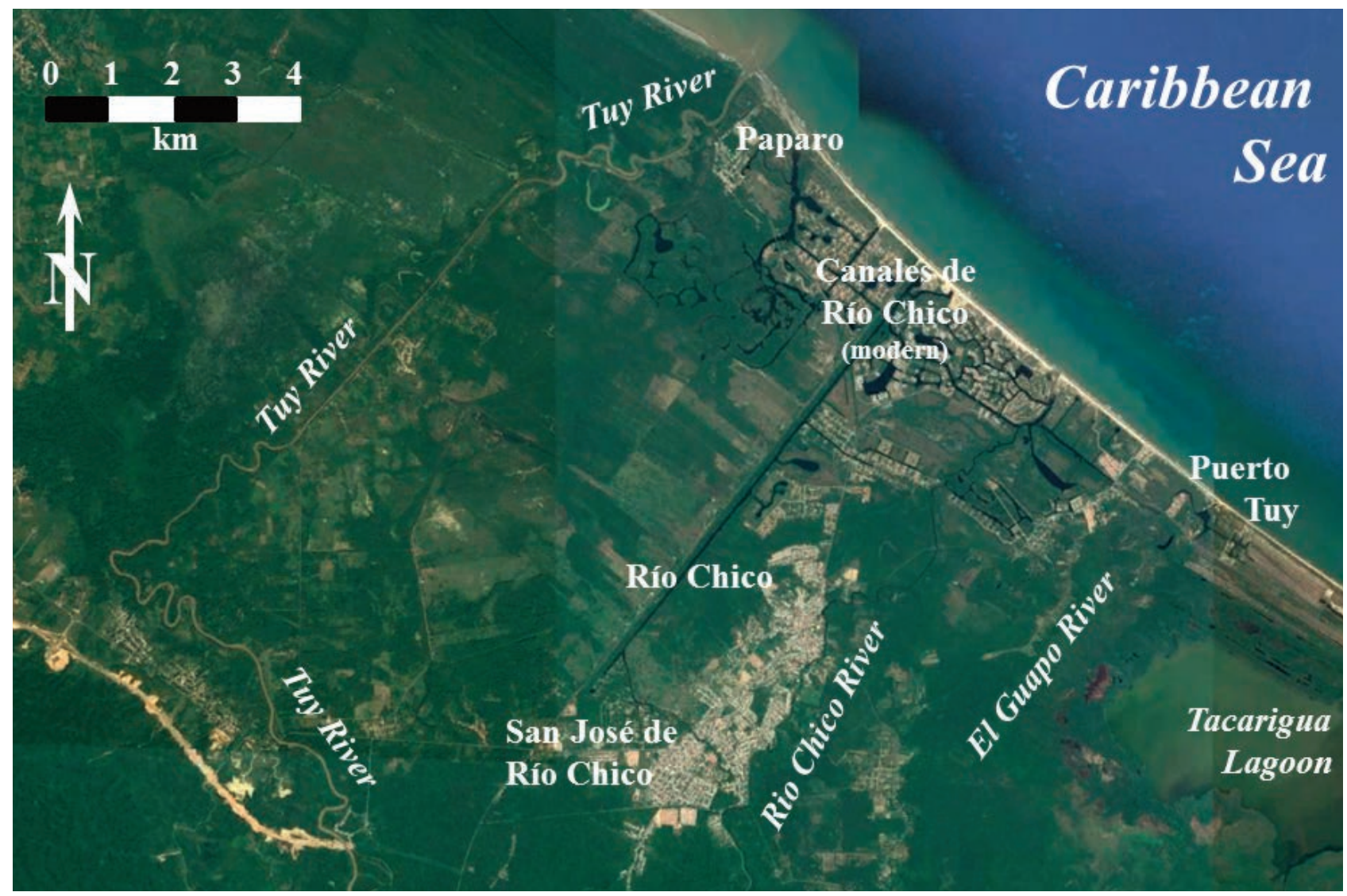

Figure 11. Google Earth map of the Barlovento coast between the Tuy and Guapo river mouths. All accounts from this region as to the 1900 tsunami come from this stretch of low-lying flat coastal plain. 
vertimento durante todo el día a los chiquillos (...) Media hora después del cataclismo crecieron las aguas de los ríos sin que antes ni después de aquel aciago momento hubiese llovido en sus lechos." (In San José, village located less than 2 miles from Río Chico (Figure 11), the river that crosses town flooded over on both sides, watering the streets before returning to its natural riverbed. This is even worse if considering that one of the river bank is $4 \mathrm{~m}$ higher than the river course. This was seen all along the river course, throwing on land countless fish that fed the population during those dreadful days; and were used as toys by kids the day long ..... Half an hour after the cataclysm, the river waters were raised without any rain before or after that terrible moment -FTBA-).

To understand the relevance of these accounts, the coastal area of Barlovento, along the Barcelona Embayment shore, needs to be described (Figures 3 and 11). The Barlovento Depression exhibits a flat-lying topography, bounded by a sandy beach that is usually less than $1.7 \mathrm{~m}$ high. This alluvial plain extends far inland with almost no relief for tens of kilometers, being the villages of Paparo (ca. $0.7 \mathrm{~km}$ inland), San José (ca. 7.5 $\mathrm{km}$ inland) and Río Chico (ca. $5 \mathrm{~km}$ inland) not far from the coastline, while Puerto Tuy sits right on the beach, at the mouth of the Guapo River (Figure 11). The October $29^{\text {th }}, 1900$ earthquake strikes this region before sunrise, still at full darkness (4:40-4:45 am local time) and the tsunami, as mentioned by one of the accounts, strikes the region around half an hour later, still at dark. We still actually wonder how an eyewitness could reliably see anything at nighttime, and furthermore, how he could survive a $10 \mathrm{~m}$ high wave in an area with neither any natural elevation nor vertical escape except for tall trees. If the other accounts are analyzed in detail, it would be more appropriate to believe that riverbore actually took place, in which case, the water elevation could reach up to 3-4 m, eventually to $5 \mathrm{~m}$ above riverbeds at most at up to $7 \mathrm{~km}$ inland from coastline, considering that houses were half drowned and they were on river banks (inundation height of $1.5 \mathrm{~m}$ above alluvial plain at most; equivalent to mid-height of bahareque houses), which are 3 to $4 \mathrm{~m}$ above the riverbed in normal conditions.

At Los Roques Archipelago (Figure 3 inset), Espíndola [1900] writes a note, entitled El terremoto en Los Roques, in the newspaper La Religión, which appears published a week after the event (on November $06^{\text {th }}$, 1900). A pertinent extract goes: "Una fuerte conmoción seísmica se ha sentido en esta isla y los islotes circunvecinos a las 4 y 40 minutos de la madrugada de hoy (...) Se oyeron estampidos sordos, como de poderosa artillería, la atmósfera se oscureció por largo tiempo y el mar se retiró mugiendo a muchos metros de la playa. Los tripulantes de las embarcaciones que han llegado a este puerto en lo que va ocurrido del dia, y que navegaban en los canales de estas islas, me dicen haber oido las mismas detonaciones, al tiempo que sintieron sacudidas violentas y una agitación extraña en las aguas". Our free translation (FTBA) goes: A strong shaking was felt on this island [Gran Roque] and other smaller keys at 4:40 am today (...) Booms were heard, as those of powerful artillery, sky got dark for quite a while and sea retreated mooing at many meters from the beach. Ship crews who have disembarked during the day, and were sailing between the archipelago islands, tell me they have heard the same booms, at the same time that they felt strong shaking and a strange motion of sea waters.

Combining, the descriptions of towns sitting on Barlovento seashore and Los Roques Archipelago, we could say that the 1900 earthquake epicenter would apparently seem closer to Los Roques than Paparo and San José, based only on earthquake noise hearing. Since there is no noise reporting at the southern site, we do not know if it corresponds to an actual lack of noise or a lack of description by locals. On the other hand, this tsunami waves exhibit a striking feature. Both at Los Roques Archipelago and Barcelona Embayment at Barlovento, significant initial sea retreat has been reported, about $1 \mathrm{~km}$ in Barlovento and "many meters" at Gran Roque. Considering the tsunami could be eventually triggered by tectonic slip along the SSF, each of the 2 abovementioned sites sits on opposite sides or blocks across the fault, where initial water oscillations would be expected to behave in opposed manner. Would this imply a submarine slide origin, or even any other source, for this earthquake-related tsunami, as proposed by other previous authors??

From the damage to buildings at Barlovento, where dwelling and warehouse drowning seems a common feature nearshore (Puerto Tuy) and several kilometers inland (Río Chico and San José de Río Chico), inundation appears not to be catastrophic but rather slow instead, more like a rising flood, suggesting that riverbore took place at the lowermost stretch of several rivers. Then, assigning an ITIS-2012 intensity level is not straightforward. Inundation during this tsunami is reported up to $7.5 \mathrm{~km}$ inland but only close to river. Little flow damage seems to have been recorded by dwellings. From damage descriptions, it appears to range between IV (largely observed) and V (strong). However, damage might have been minimized by the height of terrace risers (about $4 \mathrm{~m}$ above riverbed), on which houses were built, and inundation progression substantially slowed down by dense tall tropical vegetation few kilometers inland. If tsunami height (or 
tsunami flow depth enhanced by riverbore effect of 4.5$5.0 \mathrm{~m}$ ) is taken into consideration, the intensity of this tsunami may reach as high as IX (destructive). Meanwhile, at Los Roques Archipelago, intensity V (strong) may be assigned on the basis of most boats, while sailing between islands of the archipelago, felt strong water shaking.

Centeno Graü [1900], a young civil engineer who would compile the first seismic catalog of Venezuela many years later [Centeno Graü, 1940], writes a note in the newspaper La Linterna Mágica, on November $15^{\text {th }}, 1900$, entitled Interesantísimo estudio. The following extract refers to the tsunami effects around Barcelona: "En el mismo puerto "El Rincón" que he mencionado anteriormente, uno de los caños del río Neverí se angostó como más de 2 metros, los árboles de sus riberas están arrasados como por un temporal. Este caño está en terreno de aluvión muy reciente. El nivel de las aguas del Neverí se levantó a juzgar por uno de los caños: el de Puente Colorado. Este caño no corría desde hacía tiempo porque su embocadura, con los detritus y sustancias vegetales, quedó más alta que las aguas del Neverí. Al día siguiente del movimiento seísmico y en mis exploraciones noté que dicho caño estaba corriendo en abundancia. A los pocos dias volví, y ya no corría. Fui a su embocadura, y me cercioré que esta es más alta, con un metro, que el Neveri". FTBA is as follows: In the same El Rincón seaport that I mentioned before, a channel of the Neverí River (Figure 3) got narrower in more than $2 \mathrm{~m}$, and the trees on its riverbanks are torn down like by a strong wind. This channel incises very recent alluvial sediments. Water level of the Neverí River seems to have been raised, based on one of its channel, the one under the Colorado Bridge. This channel had been dry for a long time because sediments and dead trees at its mouth raised its river bed above the Neverí waters. The day after the earthquake, during my field explorations, I observed running water in that channel. Few days later, it went dry again. I went to its mouth, and confirmed it was a meter higher than the Neverí River level.

The detailed descriptions by Centeno Graü [1900] clearly attest to his observational skills, not only as an engineer but also as a naturalist. By the way, the best descriptions of damage by this earthquake were undoubtedly his. He even estimated the possible epicentral area of this earthquake [see Colón et al. 2015 for more details). Based on his observations on water levels and relative river bed heights narrated above, we have estimated that water level has been raised at $\mathrm{El}$ Rincón seaport by about $2 \mathrm{~m}$, eventually $3 \mathrm{~m}$, since water was running on the higher and commonly abandoned channel of the Neverí River. In addition, river- bore seems to have happened here as well, enhancing the coastal flooding at the Neverí River delta. In addition, the fact that trees (of unknown species and robustness) are torn or broken down along the river channel, it allows estimating the run-up height at least at $3 \mathrm{~m}$. This effect (generation of garbage) in the environment allows to classify it as intensity VII [damaging; Lekkas et al. 2013] at least. The herein estimated tsunami wave height may upgrade it up to intensity VIII (heavily damaging). Collected damage descriptors are useless to assign an Imamura-Iida magnitude (Iida, 1963], but can be classified as grade 1 from estimated tsunami wave height.

Summing up: 1) the tsunami associated to the 1900 earthquake was recorded at three sites (Figures 3 and 11): A) Gran Roque and others keys of Los Roques Archipelago, B) Barlovento coast (between Paparo and Puerto Tuy) and as inland as Río Chico (5 km from seashore) and San José de Río Chico (7.5 km from coastline), both on margins of the Río Chico River, and C) Neverí River mouth, at El Rincón seaport (Barcelona). 2) Riverbore is common to most localities on the Barlovento coast (Figure 11): Paparo next to Tuy River mouth, Puerto Tuy at El Guapo River mouth, and Río Chico and San José de Rio Chico along the Río Chico River. Same situation happens at El Rincón seaport, near El Dorado Bridge. 3) Sea retreat was noticed at Gran Roque and at Barlovento; up to $1 \mathrm{~km}$ at the latter one. No observation has been found for Barcelona yet. 4) Maximum run-up height is: A) $5 \mathrm{~m}$ above river level (1.5 $\mathrm{m}$ above alluvial plain) along the Río Chico River, B) at least $3 \mathrm{~m}$ above the water level of the Neverí River at El Rincón seaport (Barcelona); and C) less than coastal sand barrier height at Gran Roque leeward side (less than $1.5 \mathrm{~m}$ ). From the number of tsunami reports and their spatial distribution (size of their felt area), this is the largest tsunami of all tsunamis produced by a local earthquake in eastern Venezuela. In fact, based on the extent of the area with tsunami reports, which is in the order of 250-300 km long (distance between Los Roques Archipelago and Barcelona; Figure 3), the magnitude of this tsunami would be less than 3 , and most likely magnitude 2, by applying the Imamura-Iida tsunami magnitude scale [Iida, 1963].

\subsection{The July $15^{\text {th }}, 1853$ tsunami}

Five different eyewitness accounts tell us about this earthquake and its associated tsunami. All accounts report on Cumaná, but two of them refer to a strong aftershock that took place on August $3^{\text {rd }}$, almost 3 weeks later. These two accounts also provide information about two other localities: Barcelona, which is located 
some 30-40 km WSW of Cumaná and farther into the Barcelona Embayment, and the Coche Island (Figure 3).

The first account that we could find, says: "El mar se retiró algunas varas al principio del terremoto, y como si hubiese recogido sus fuerzas, volvió después con un impetu extraordinario penetrando más de cien varas en todo el rededor de la población. Algunos chorros de aguas termales brotaron de repente y las aguas del Manzanares, que divide la población, se elevaron algunos pies en ese instante" (Anonymous eye witness, 1853; La catástrofe de Cumaná. Folletos, Academia Nacional de la Historia, Caracas). FTBA goes more or less like this: "Sea got away some rods [vara $=0.835 \mathrm{~m}$ or about 33 inches] at the beginning of the earthquake, and as if it had put together all its strength, came back with an extraordinary rush, invading over a hundred rods [ $>85 \mathrm{~m}]$ all around town. Some hot water springs suddenly appeared and the waters of the Manzanares River, which run across town, were then raised few feet".

"Como ahora siglos, el mar inundó una gran parte del Salado. Se desbordó el rio Manzanares que atraviesa la ciudad" (Diario de Avisos y Semanario de las Provincias, Caracas: 27 de julio de 1853). This second account can be translated as follows: "Today as few centuries ago [probably referring to the predecessor 1530 tsunami], sea inundated a large portion of El Salado [coastal neighborhood of Cumaná]. The Manzanares River that crosses the city, flooded over its banks" (FTBA).

The two following accounts refer to the large aftershock felt in Cumaná, in August $3^{\text {rd }}, 1853$. "Se nos informa al poner en prensa este número que el 3 del corriente ha sufrido Cumaná otra fuerte conmoción de tierra que ha derribado muchas de las casas que quedaban en pie después del terremoto del 15. El Neverí se ha desbordado, inundando gran parte de la ciudad de Barcelona" (Diario de Avisos y semanario de las provincias, Caracas: 10 de agosto de 1853). Translation (FTBA) goes: "We have been informed when printing this issue (of Diario de Avisos y semanario de las provincias in Caracas on August $10^{\text {th }}, 1853$ ) that Cumaná on August $3^{\text {rd }}$ has suffered another strong ground commotion (shaking), which has pulled down many of the still standing houses spared by the earthquake on the $15^{\text {th }}$. The Neverí [River] has flooded over, inundating most of the city of Barcelona". From this account, it is still unclear to the authors when the Neverí flooding occurred: on July $15^{\text {th }}$ during the main shock or on August $3^{\text {rd }}$ with the large aftershock? Grases et al. [1999] relate the account on the Neverí flooding to the aftershock.

"El ulttimo temblor de esta ciudad [Cumaná] tuvo lugar en la noche del 3 de Agosto. Asegúrase que surgieron manantiales de agua subterráneos, y que el mar volvió a invadir parte de la costa por el lado del Dique, dejando una profundidad de
14 brazas" (Diario de Avisos y semanario de las provincias, Caracas: 13 de agosto de 1853). The translation (FTBA) goes: the last earthquake in Cumaná happened on the night of August 3rd. People are persuaded that underground waters were spouted, and sea invaded again the coast by El Dique [neighborhood of Cumaná located on the northern bank of the Manzanares River near its mouth; Figures 7.9 and 10a]-, leaving a depth of 14

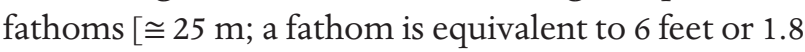
$\mathrm{m}$ approximately]".

The fifth account seems to confirm most of what the eyewitness of the first account reported: "El mar, salvando sus limites conocidos inundo en una extensión de 200 varas, las sabanas del Salado y Caigüire, sumergiendo un alijo cargado de maiz, que acababa de llegar a la playa. Una embarcación sintió intensamente el sacudimiento en frente de la isla de Coche" [Beauperthuy 1853]; Otra relación del terremoto de Cumaná En: Diario de Avisos y semanario de las provincias, Caracas: 10 de septiembre de 1853). This report goes: "Sea, leaving its known limits, inundated an extension of 200 rods [about $170 \mathrm{~m}$; vara $\cong 33$ inches or $85 \mathrm{~cm}$ ] in El Salado and Caigüire flatlands, drowning a corn supply or stockpile, which had just arrived to the beach. A boat felt strong shaking off Coche Island (Figure 3).

From these five accounts, several facts can be deduced: 1) A large aftershock on August $3^{\text {rd }}$ accompanied the July $15^{\text {th }}$ main shock, and both were felt in Cumaná. 2) The 1853 tsunami is not the first one suffered by Cumaná. When describing the 1853 event, the writer mentions it is not the first time that El Salado is drowned by tsunami waves. 3) The sea retreated at Cumaná before inundating the city on July 15th, 1853. 4) Inundation was in the order of a hundred to two hundred "rods" (varas) on flat-lying areas such as Caigüire or El Salado (in fact, salt-flats; Figure 12); in other words, actual inundation was between 85 to 170 $m$ inland. 5) Inundation takes place preferentially along rivers, both the Manzanares in Cumaná and Neverí in Barcelona. 6) Caigüire is also inundated; not only El Salado. Caigüire lies at the former east end of Cumaná (in 1960's), on the southern coast of the Cariaco Gulf entrance (Figure 12), and not on open sea, such as El Salado or El Dique. 7) It is still unclear to us whether the Neverí inundation happened during the main shock on July $15^{\text {th }}$ or a large aftershock on August $3^{\text {rd }}$, because of the way the news is reported. We however suspect it is associated to the main event. 8) The sea surface shaking is spotted off the coast of Coche Island, to the north (Figure 3). 9) Maximum run-up height is not easily discernable. For instance, the first account expressly says: "Manzanares River waters were 


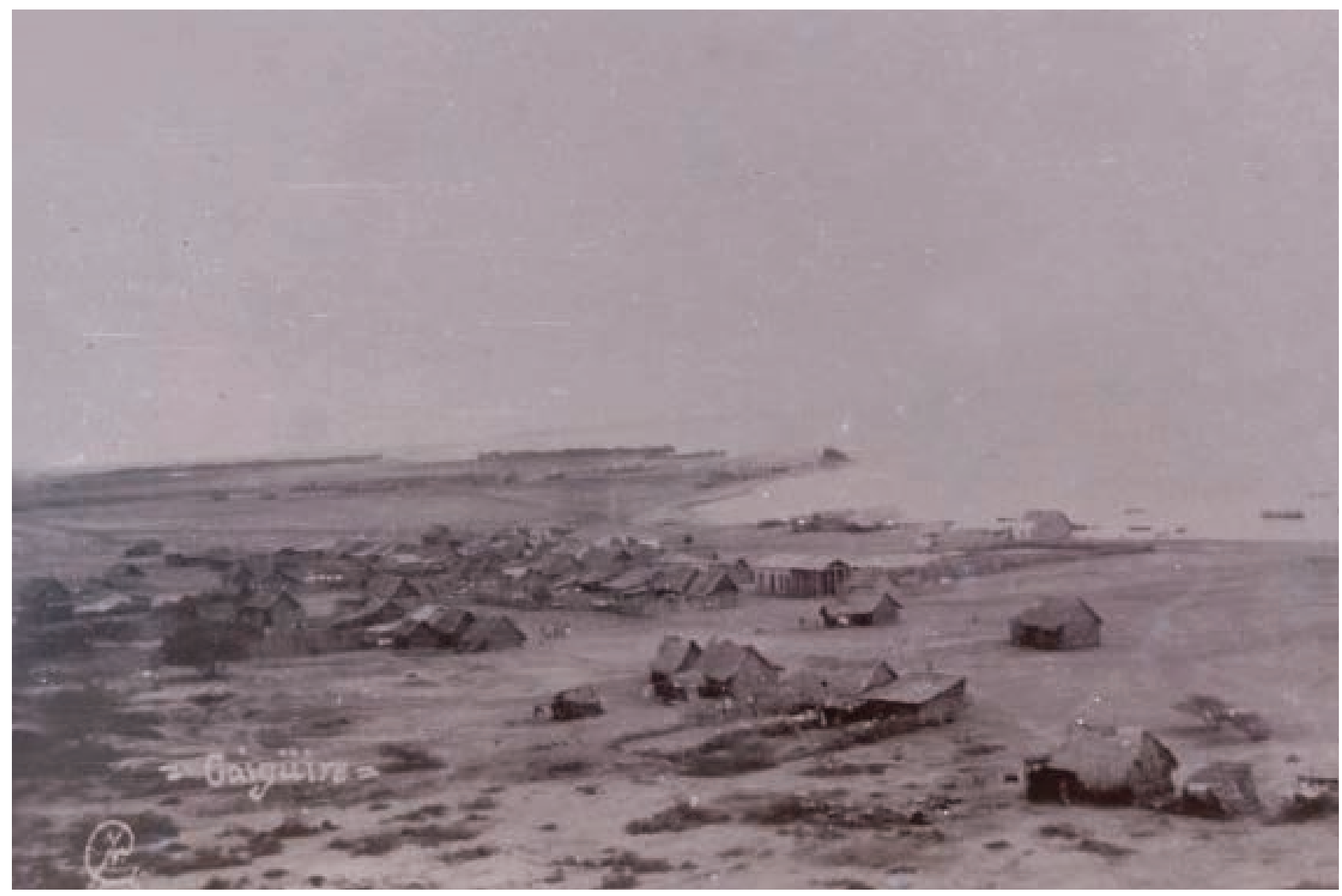

Figure 12. Bird-eye to the NW of the Caigüire sector, taken in 1925. Note the mangrove trees by the seashore in the far background. Today, the Perimetral Avenue runs there. Also notice the low-lying flat topography of the salt-flat, on which are built the wooden huts of locals. That is the view of a typical fisherman village of the time.

raised few feet", near the river mouth (El Salado), while the second one indicates that went over its banks. Nowadays, the Manzanares River near its mouth hardly incises down by a meter or so (Figure 13). This would imply that tsunami height, better to say riverbore height, would have needed to be over a meter (or two?). But the fifth account brings additional

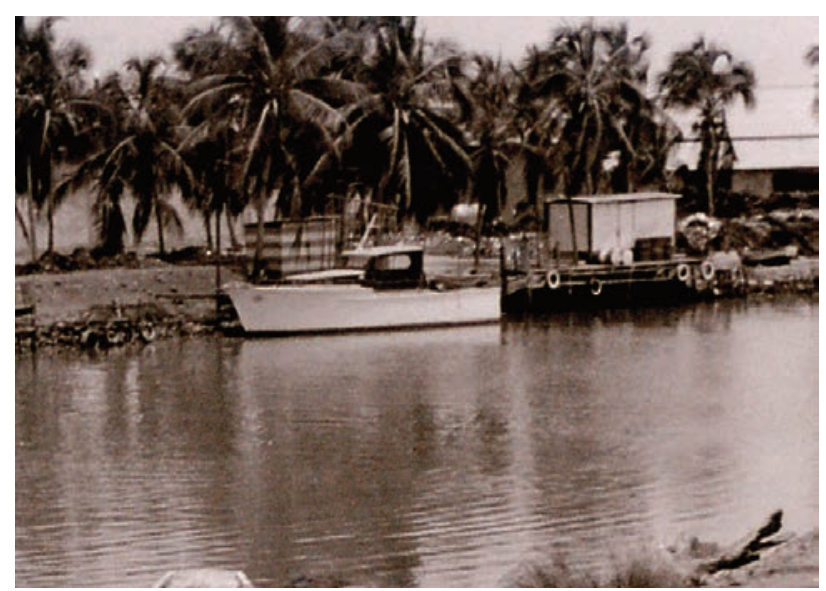

Figure 13. View of the Manzanares River near its mouth. The Simón Berrizbeitia's Monalisa yatch stands for scale. Riverbanks are less than $1 \mathrm{~m}$ high above river level. Higher grounds correspond to river protection embankments, which are also visible in Figure 7 , coconut trees in both figures are comparable. information about this inundation in low lying flatlands or saltflats. Beauperthuy [1853] says that a corn stockpile on the beach was drowned. In doing so, tsunami waves would have required to be at least 2 to 3 meter high to go over both the coastal sand barrier and the corn supply sitting on it, since the current sandy beach around El Salado and Caigüire is already about $1.5 \mathrm{~m}$ high. This maximum run-up height of about $3 \mathrm{~m}$ seems to be in good agreement with some $200 \mathrm{~m}$ of tsunami inundation. Hafeez [2008] measured, after the December 2004 Indian Ocean tsunami, inundation distances and run-up heights at different Indian localities, obtaining a rather linear relationship between both parameters (his figure 3). Particular interest for us shows two of his localities with similar topographic conditions and relative locations to our current study case. The Rajakkamangalam and Manavalakurichi lie at the mouth of the Panniyar and Valliyar river mouths, respectively [Hafeez, 2008]. This author expressly indicates "these rivers also contributed to such a huge amount of inundation". Riverbore appears to have taken place in such cases. The Inundation distance and run-up height at Rajakkamangalam were $350 \mathrm{~m}$ and 3-4 m, respectively; and they were at Manavalakurichi $250 \mathrm{~m}$ and 3-4 m, 
respectively [Hafeez, 2008]. In other words, a rough relation of 1 to $70-100$ can be established between run-up height and inundation, for localities sitting on lowlying coastlands near rivers. Consequently, a $200 \mathrm{~m}$ inundation distance appears to go well with a 3 m run-up height for the 1853 tsunami in Cumaná. Finally, the meaning of "leaving a depth of 14 fathoms", equivalent to some $25 \mathrm{~m}$, remains unclear to the authors.

By applying ITIS 2012 scale (Lekkas et al. 2013], the tsunami at Coche island can be categorized as intensity IV (largely observed) at least, since it was felt onboard small vessels or boats. Meanwhile, the facts that the Manzanares river rose few feet and inundated close to $200 \mathrm{~m}$ inland along Cumaná western shore, with no other damage descriptors, allow to establishing a minimum intensity of VII [damaging; Lekkas et al. 2013]. Its magnitude by applying Imamura-lida scale, is at least 0 at Cumaná.

\subsection{The September $1^{\text {st }}, 1530$ tsunami}

Three different testimonies describing the 1530 tsunami are here evaluated. The first account of the three is from Fernández de Oviedo y Valdéz. It says: "El año de mill é quinientos é treynta, en el mes de septiembre, en un día sereno é tranquilo, en un instante, á las diez horas del día, en la provincia de Cumaná se levantó el mar en altura de quatro estados é juntamente dio la tierra un horrible bramido, é inundóse la tierra, sobrepujando la mar sobre ella..." (Fernández de Oviedo y Valdés, Gonzalo [(1535)1851] Historia General y Natural de las Indias. Islas y Tierra Firme del Mar Océano. Primera Parte. Imprenta de la Real Academia de la Historia: Madrid). The story goes: "In 1530 , in September, in a quiet and peaceful day, at 10 in the morning, in the Province of Cumaná, the sea raised in 4 "estados" [over $13 \mathrm{~m}$; 1 "estado o estadal" = 4 "varas" or stick $=4 \times 0.835 \mathrm{~m} \cong 3.34 \mathrm{~m}]$ and the earth bellowed horribly at the same time, and land was drowned, running waters over it...".

The second account on the 1530 earthquake and tsunami comes from a letter of Deputy Mayor Andrés Villacorta to the Canonry of Nueva Cádiz that says in Spanish: "Oy jueves, primero de setiembre de mill e quinientos e treynta años, a ora de las nueve se levantó el mar de tal manera ques cosa milagrosa a los que la vieron y entró dentro de esta tierra donde estava sytuada esta fortaleza, e con ello dio un bramido la mar e tenbló la tierra tres vezes en media ora, e abrióse por muchos lugares, e con el tenblor cayó esta fortaleza hasta los cimientos" [Carta de Andrés Villacorta, Teniente de Alcaide, al Cabildo de Nueva Cádiz, a razón del terremoto de 1530, Citado en Otte, 1977: 243]. The FTBA goes as follows: "Today, Thursday September 1st 1530, at around 9 in the morning, the sea raised in such a way that was a miracle who could tell about it, and went inland where the fortress is situated, and the sea bellowed once, and land shook three times in half an hour, and cracked wide open in many places, and the fortress fell down to its foundations".

The third testimony is much more elaborated and abundant in details in many different relevant aspects: “...y al otro día siguiente vino la nueva de cómo la fortaleza de Cumaná era cayda del gran temblor e terremoto y se abrió la tierra en muchas partes y salió la mar de sus términos (...) y el mismo dia viniernon ciertos yndios... los quales dixeron que se avia anegado un pueblo questava a dos leguas de alli e que ellos avian salido a nado donde murieron quatro yndios e muchos muchachos e perdieron toda su ropa (...) Temblo la tierra veynte $y$ tres veces a cada vez que temblaba la Tierra bramaba debajo della de una manera espantosa e vido viniendo por el dicho golfo... quel agua de la mar salio de sus limites y los dichos indios decian que bramó la mar como leon (...) e vido los arboles arrancados y encima de otros arboles a donde salio la mar de sus términos e vido algunos peces colgados netre las ramas [producto] del gran terremoto e vido otros arboles de mangle que son muy rezios e muy gordos quebrados del dicho terremoto e otros arrancados de rayz e otras cosas de mucha admiración" [Información hecha en la Isla de Cubagua, 1530].

The free translation by authors (FTBA) goes: “... and the day after, the news arrived that the fortress of Cumaná was pulled down by the great tremor and earthquake, and land opened in many places and sea left its boundaries (...) the same day some Indians came... who said that a village at 2 leagues away (about $11 \mathrm{~km}$ away; league $=6666.7$ "varas" or sticks $=5572.7$ $\mathrm{m}$ ) was drowned and they were able to escape swimming while 4 Indians drowned and many young people had lost all their clothing (...) Land shook 23 times; each time Earth trembled, it bellowed underneath in a horrible way, seen as coming by the gulf [Cariaco Gulf located due east of Cumaná]... that seawater went out of its limits and those Indians mentioned that sea roared like a lion (...) trees were seen unrooted and piled on top of others where sea inundated, and some fish were seen hanging in tree branches because of earthquake, and mangrove trees, which are very strong and robust, were broken by the earthquake and others fully unrooted, and others things of much admiration". For Grases et al. [1999], the latter part of the account by the Indians takes place into the Cariaco Gulf, located due east of Cumaná (Figure 3).

As expected, the information about this 1530 earthquake and associated tsunami is more complex to unravel, but many details, however, are provided.

As to the earthquake, we can express the following: 1) Day and time of occurrence is very well estab- 
lished: in midmorning (9-10 am) of Thursday September $\left.1^{\text {st }}, 1530.2\right)$ Both earthquake and tsunami takes place. Time lag between earthquake and tsunami seems short. 3) Earthquake epicenter is close to Cumaná. Many accounts refer to loud noises, like roaring, booming or bellowing, accompanying shaking. 4) Many earthquakes (aftershocks) were felt at Cumaná after the main shock, up to 23 ; most of them also accompanied by loud noise from the ground. 5) Roaring in some cases would seem to come from the Cariaco Gulf, due east of Cumaná, which would be in contradiction with a focus on the Cariaco Trough, located west of Cumaná, as proposed by Audemard [2007]; unless some echo effect or reverberation is called upon. 6) The fort built by Jácome Castejón was torn down to its foundation by the earthquake and not by the tsunami.

As to the tsunami, we can list the following facts: A) Inundation is reported both at Cumaná and at a village $11 \mathrm{~km}$ (2 leagues) away (Figure 3). Being this village around the Cariaco Gulf, the locality, which should suit favorable conditions for Indian settling and land cultivating at the time of the earthquake and tsunami, as well as exhibiting a topographic situation prone to drowning during high waves inundation, is the delta plain of either Guaracayal or Mariguitar, that lie 18 to $23 \mathrm{~km}$ due east from Cumaná (Caigüire), respectively B) Wave height of tsunami waves seems to be significantly high since someone reports "lucky ones those who could tell about the sea rise". At the nearby village, Indians had to swim to survive and four of them drowned. This also implies that run-up has to be few meters high. This seems to confirm the description provided by Centeno Graü [1969], which indicates that sea got some meters above its normal level, leaving the beach dry and when returning, it inundated most of the city existing at that time. C) However, waves as high as $13 \mathrm{~m}$ (4 estados) seem an exaggeration to us, although some reports indicate that waves went over treetops at Manzanares river mouth [see Audemard 2007, for more details]. D) Using plants as a height reference, we must indicate that two main plant species are common to this seashores and river banks at Cumaná: coconut and mangrove trees (Figures 7, 10a, 12,13 and 14), particularly Rhizophora sp. In the referred case, waves as high as 5 to $7 \mathrm{~m}$, as interpreted by Audemard [2007], would be large enough to go over mangrove trees and leave fish hanging from its branches, as reported in the third account. E) A better bracketing of wave height can be provided from the fact that robust mangroves (probably Rhizophora trees) were torn down and even some specimens have their roots pulled out completely, as mentioned in the third account.
Based on recent studies of damage to mangrove populations, in Banda Aceh, Indonesia, and Pakarang Cape, Thailand, as a result of the devastating Indian Ocean 2004 tsunami, Yanagisawa et al. [2010] found that more than $50 \%$ of mangrove trees with $20-25 \mathrm{~cm}$ [very robust] stem diameter at breast height (DBH) could survive a tsunami of less than 6-7 $\mathrm{m}$, although mangrove trees were destroyed completely under 7-9 $\mathrm{m}$ or higher tsunami waves. We feel that coastal morphology, plant populations, shelf configuration and profile, between these two Indian Ocean study sites and the Cumaná region are pretty much similar. Therefore, their conclusions can be extrapolated to our case. In a previous study, Yanagisawa et al. [2009] categorize damage to mangrove trees into five patterns: (1) broken at stem or prop roots, (2) uprooted and inclined, (3) uprooted and fallen down, (4) uprooted and swept up by tsunami flow, and (5) lost bearing capacity because of ground erosion. However, the same authors indicate that Rhizophora trees were destroyed only slightly in the patterns resembling patterns (2)-(4) because the prop roots of Rhizophora trees are sufficiently thick to resist the tsunami flow. They add that when pattern (5) does not show, pattern (1) is mostly applicable as the predominant damage pattern of Rhizophora trees. Then, from the description of damage to mangrove populations during the 1530 tsunami waves given in the third account, it would seem that pattern (1) and (3) were the two most common, implying that low-lying coastal plain erosion did not take place then. Although we do not know the actual stem diameter of the mangrove trees affected during the 1530 event in Venezuela, it would appear that no total destruction of tree population occurred. It would seem to point to flow depths during the Cumaná event below $7 \mathrm{~m}$. F) Audemard [2007] indicated that tsunami waves at the Manzanares River mouth (north part of the old city) flooded inland as far as the ranges (Caigüire Hills?). As applied for the 1853 tsunami herein, the inundation distance may give as clues as to the run-up heights. In old maps of the city of Cumaná, the river mouth was some $500 \mathrm{~m}$ away from the Caigüire hills foothills, although they are just over 2 km away nowadays. From a map by Beltrán and Rodríguez [1995], a coastal advance, likely strongly influenced by anthropogenic processes since the early 50 's, of some $130 \mathrm{~m}$ has happened in less than 50 years, between 1937 and 1981. So, despite the low precision of old maps, before the instrumental -theodolite- era, the delta plain of the Manzanares River since the foundation of the city of Cumaná in $1515 \mathrm{AD}$, has surely substantially changed, particularly advanced through the years. In any case, an inundation distance of at least $500 \mathrm{~m}$ 
would allow estimating a lower bound for the run-up height in the order of $5 \mathrm{~m}$. Consequently, the run-up height in Cumaná, characterized by a flat morphology typical of a young prograding delta, would be ranging between 5 (from inundation distance) and $7 \mathrm{~m}$ (damage to Rhizophora trees). This value range is consistent with an earlier estimate proposed by Audemard [2007].

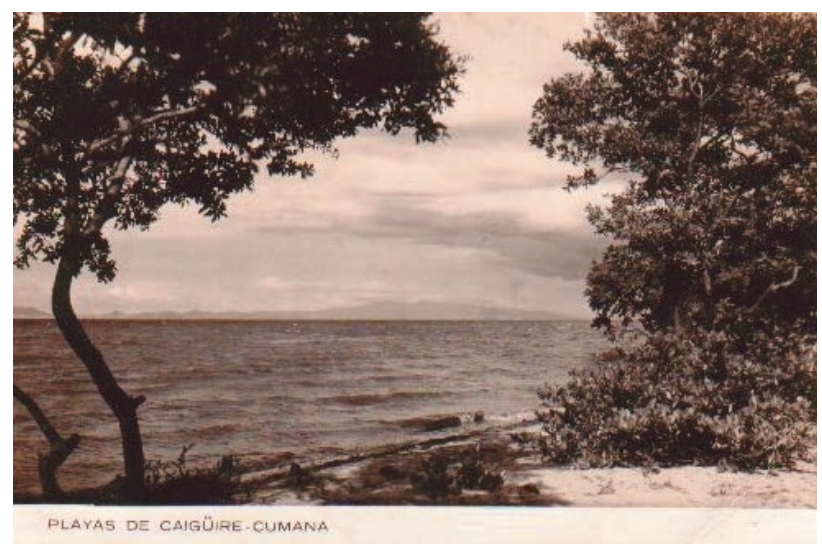

Figure 14. Beach at Caigüire in 1960's, where mangrove trees grow almost on the sand barrier, which is visible between trees. Also notice the height of sand barrier above sea level.

The occurrence of Indians drowning (at village in the Cariaco Gulf) and mangrove trees tearing and uprooting (at Caigüire, Cumaná) during this tsunami both allows to estimating a minimum ITIS-2012 intensity of VIII (heavily damaging; Lekkas et al. 2013]. This also determines the tsunami magnitude to be grade 2 in the Imamura-Iida tsunami magnitude scale [Iida 1963]. If the tsunami wave height happens to be between 5 and $7 \mathrm{~m}$, as proposed after this research, the assigned ITIS 2012 intensity can be as large as X (very destructive).

\section{Concluding remarks}

The first striking commonality from the historical evaluation of eyewitness accounts is that inundation for all these earthquakes are reported at river mouths or settlements on their mouths (Figures 3 and 11): Tuy, Río Chico, Guapo, Neverí, Manzanares. From comparison with modern analogs, such as the Valdivia 1960, Camaná 2001, Sumatra 2004, and Tohoku-Ochi 2011 tsunamis, this is not surprising because inundation and wave invasion happens sooner, faster and more efficiently along rivers, through the river mouth and along the incised river channel. As a matter of fact, seawater invasion during tsunami wave progression shows a prominent acute salient at river mouths. The explanation is obvious: there is no natural barrier blocking the landward wave progression. In addition, the water invasion is eased by the lower level of the coastland area resulting from river incision. This also drives that maximum inundation tends to happen and occur along rivers. However, a major difference between the Venezuelan historical tsunami events and those abovementioned needs to be underlined. It refers to the size of river discharge in Venezuela. As a country lying in the Tropics, river flow is hardly negligible and appears to be significantly higher than for the other cases. For instance, the Manzanares River, which is a small river for our standings, has an average annual discharge of $560-770 \times 106 \mathrm{~m}^{3}$, which is equivalent to some $15 \times 10^{6}$ $\mathrm{m}^{3} /$ month, or $5,63 \mathrm{~m}^{3} \mathrm{~s}^{-1}$ (ranging between 3.5 and 7.0 $\mathrm{m}^{3} \mathrm{~s}^{-1}$ ) at river mouth [Medina et al. 2013]. This then surely leads to the formation of riverbore when both waters (tsunami wave and river flow) encounter at river mouths, rising river level and significantly flooding over banks. Then, this may have fundamental implications on the dynamics of the inundation process, as well as on characteristics of the tsunami waves, particularly as to wave height. In other words, flooding heights along rivers when riverbore occurs, are not necessarily the same as maximum run-up heights, but should tend to provide a rather precise lower bound.

The other common fact is that the city of Cumaná has been affected by tsunami waves associated to all 4 events occurring on the EPF but not by the $1900 \mathrm{AD}$ event, the largest of all 5 events assigned to SSF, whose epicenter lies close to the far west end of the Barcelona Embayment (Figure 3). Nevertheless, it is a fact that there are more frequent and more widespread eyewitness accounts on the tsunami waves during the 1900 AD event (Figure 3). A larger area of affectation by tsunami waves definitely support its larger earthquake magnitude: Gran Roque Island of the Los Roques Archipelago and river mouths of Tuy, Río Chico, Guapo and Neverí. All these rivers drain into the Barcelona Embayment; Neverí on the SE while all others on the SW (Figure 3).

Another outcoming commonality is that the value of the run-up height (in all our cases equivalent to the water depth of the inundation, because all affected localities sit on low-lying coastlands) from such eye-witness or first-hand testimonies not necessarily are rid of subjectivity. However, combining a good knowledge of coastal physiography, shelf morphology, natural environments and cultural aspects (construction types, housing, customs, life style, vessels, among many others) of affected populations at the time of occurrence of tsunamis with a thorough and careful reading of the testimonies, may lead to find ways of bracketing both inundation distances and run-up heights for any given historical tsunami. For instance, an eye-witness during the 1900 earthquake reports tsunami waves of $10 \mathrm{~m}$; or $13 \mathrm{~m}$ during the 1530 tsunamigenic earthquake. Simi- 


\begin{tabular}{|c|c|c|c|c|c|}
\hline \multirow[t]{2}{*}{ PARAMETERS } & \multicolumn{5}{|c|}{ EARTHQUAKE/TSUNAMI } \\
\hline & 01-IX-1530 & 15-VII-1853 & $29-X-1900$ & 17-I-1929 & 09-VII-1997 \\
\hline $\begin{array}{l}\text { Epicenter } \\
\text { Coordinates }\end{array}$ & $\begin{array}{c}10.261^{\circ} \mathrm{N}, \\
64.313^{\circ} \mathrm{W} \\
\text { (estimate; } \\
\text { Rodríguez et al., } \\
\text { 2006) }\end{array}$ & $\begin{array}{c}10.265^{\circ} \mathrm{N}, \\
64.359^{\circ} \mathrm{W} \\
\text { (estimate; } \\
\text { Rodríguez et al., } \\
\text { 2006) }\end{array}$ & $\begin{array}{c}10.660^{\circ} \mathrm{N}, \\
66.080^{\circ} \mathrm{W} \\
\text { (estimate; } \\
\text { Rodríguez et al., } \\
\text { 2006) }\end{array}$ & $\begin{array}{c}10.394^{\circ} \mathrm{N}, \\
64.000^{\circ} \mathrm{W} \\
\text { (estimate; } \\
\text { Rodríguez et al., } \\
\text { 2006) }\end{array}$ & $\begin{array}{c}10.545^{\circ} \mathrm{N}, \\
63.515^{\circ} \mathrm{W} \\
\text { (estimate; } \\
\text { Rodríguez et al., } \\
\text { 2006) }\end{array}$ \\
\hline $\begin{array}{l}\text { MM I } \\
\text { (with most damage } \\
\text { settlement) }\end{array}$ & X (Cumaná) & IX (Cumaná) & $\begin{array}{c}\text { IX (Guarenas- } \\
\text { Guatire \& Macuto) }\end{array}$ & $\begin{array}{l}\text { VIII-IX (Caigüire, } \\
\text { east Cumaná; } \\
\text { Audemard, 2007) }\end{array}$ & $\begin{array}{l}\text { VIII (Cariaco- } \\
\text { Casanay) }\end{array}$ \\
\hline $\begin{array}{l}\text { Magnitude } \\
\text { (Ms) }\end{array}$ & $\begin{array}{l}\text { 7.1-7.3 (estimate) } \\
\text { (Audemard, 2007) }\end{array}$ & $\begin{array}{l}\text { 7.1-7.3 (estimate) } \\
\text { (Audemard, 2007) }\end{array}$ & $\begin{array}{c}7.6 \\
\text { (Pacheco and Sykes, } \\
1992)\end{array}$ & $\begin{array}{c}\mathbf{6 . 3} \\
\text { (Audemard, 2007) } \\
\leq \mathbf{6 . 6} \\
\text { (Mocquet et al., } \\
\text { 1996) }\end{array}$ & $\begin{array}{c}\mathbf{6 . 8} \\
\text { (Baumbach et al., } \\
\text { 2004) }\end{array}$ \\
\hline Causative fault & $\begin{array}{c}\text { El Pilar -EPF- } \\
\text { (segment A) } \\
\text { (Audemard, 1999, } \\
\text { 2007) }\end{array}$ & $\begin{array}{c}\text { El Pilar-EPF- } \\
\text { (segment A) } \\
\text { (Audemard, 1999, } \\
\text { 2007) }\end{array}$ & $\begin{array}{c}\text { San Sebastián } \\
\text {-SSF- } \\
\text { (east segment) } \\
\text { (Audemard, 2002) }\end{array}$ & $\begin{array}{c}\text { El Pilar -EPF- } \\
\text { (segment B-1) } \\
\text { (Audemard et al., } \\
\text { 2007) }\end{array}$ & $\begin{array}{c}\text { El Pilar -EPF- } \\
\text { (segment B-2) } \\
\text { (Audemard et al., } \\
\text { 2007) }\end{array}$ \\
\hline $\begin{array}{l}\text { Tsunami height } \\
\text { from eyewitness } \\
\text { accounts }\end{array}$ & $\begin{array}{c}\text { Cumaná: } \cong \mathbf{1 3} \text { m } \\
\text { (4 estados; Fer- } \\
\text { nández de Oviedo y } \\
\text { Valdés, 1851) }\end{array}$ & $\begin{array}{l}\text { Manzanares River } \\
\text { rose few feet } \\
\text { (La Catástrofe de } \\
\text { Cumaná, 1853) }\end{array}$ & $\begin{array}{c}\text { Puerto Tuy } \\
\text { (Barlovento): } \\
\approx \mathbf{1 0 ~} \mathbf{~ m}(\text { Linterna } \\
\text { Mágica, 02-XI-1900) }\end{array}$ & $\begin{array}{c}\mathbf{6} \mathbf{~ m} \\
\text { (Centeno Graü, } \\
\text { 1940) } \\
\text { West Cumaná: } 9 \\
\text { feet (3 m) } \\
\text { (El Nuevo Diario, } \\
\text { 22-I-1929) }\end{array}$ & $\begin{array}{c}\text { Cumaná \& Cariaco: } \\
\leq 1 \mathbf{m} \\
\text { (González et al., } \\
\text { 2004) }\end{array}$ \\
\hline $\begin{array}{l}\text { Recalculated } \\
\text { tsunami height } \\
\text { (THIS RESEARCH) }\end{array}$ & $\begin{array}{l}\text { Cumaná: } \mathbf{5 - 7} \text { m } \\
\text { (This ratifies } \\
\text { Audemard, 2007’s } \\
\text { estimate) }\end{array}$ & $\begin{array}{c}\text { Cumaná (Caigüire): } \\
\mathbf{3} \mathbf{~ m}\end{array}$ & $\begin{array}{l}\text { Barlovento: } 5 \mathrm{~m} \\
\text { Los Roques: } \\
\quad<1.5 \mathrm{~m} \\
\text { El Rincón: } \geq 3 \mathrm{~m}\end{array}$ & West Cumaná: 3 m & $\begin{array}{c}\text { × } 1 \text { m (unchanged) } \\
\text { (González et al., } \\
\text { 2004) }\end{array}$ \\
\hline $\begin{array}{l}\text { ITIS-2012 } \\
\text { tsunami max. } \\
\text { intensity }\end{array}$ & $\begin{array}{c}\text { Cumaná \& Cariaco } \\
\text { Gulf: } \geq \text { VIII } \\
\text { (up to } \mathbf{X} \text { on tsunami } \\
\text { height) }\end{array}$ & $\begin{array}{l}\text { Coche Island: } \geq \text { IV } \\
\text { West Cumaná: } \\
\geq \text { VII }\end{array}$ & $\begin{array}{l}\text { Barlovento: IV-V } \\
\text { (up to IX on tsuna- } \\
\text { mi flow depth) } \\
\text { Los Roques: } \mathbf{V} \\
\text { El Rincón: VII (VIII } \\
\text { on tsunami height) }\end{array}$ & $\begin{array}{l}\text { West Cumaná: } \\
\text { VII-VIII }\end{array}$ & $\begin{array}{c}\text { Cumaná \& } \\
\text { Cariaco Gulf: } \\
\text { IV }\end{array}$ \\
\hline $\begin{array}{l}\text { Imamura-Iida } \\
\text { tsunami magnitude }\end{array}$ & $\begin{array}{l}2 \text { (Cumaná \& Caria- } \\
\text { co Gulf) }\end{array}$ & $\begin{array}{c}\mathbf{0} \\
\text { (west Cumaná) }\end{array}$ & $\begin{array}{c}1 \text { (Barlovento) } \\
\mathbf{0} \text { (Los Roques) } \\
\text { ? (El Rincón; } 1 \text { from } \\
\text { tsunami height) } \\
\mathbf{2} \text { (from tsunami } \\
\text { extent) }\end{array}$ & $\begin{array}{c}1 \\
\text { (west Cumaná) }\end{array}$ & $\begin{array}{c}-1 \\
\text { (Cumaná \& Cariaco } \\
\text { Gulf) }\end{array}$ \\
\hline
\end{tabular}

Table1. Summary of major parameters of the five tsunamigenic local earthquakes assessed during this investigation. It compares how tsunami heights from eyewitness accounts have been substantially reduced for some earthquakes, when the event is contextualized in time and space. The ITIS-2012 tsunami intensity scale and Imamura-Iida tsunami magnitude scale have been applied to the data provided by eyewitness accounts as well. The earthquake epicenters are shown on Figure 2 or 3.

larly, $6 \mathrm{~m}$ high tsunami waves are reported in association with the 1929 earthquake. It is very likely that the actual height of tsunami waves in all 3 cases may be half of the reported height at most, based on sound argumentation constructed from the descriptions provided by the eyewitnesses themselves (Table 1). As well, tsunami waves during the 1530 are reported to go over treetops. This may be very misleading if interpreted as it sounds. Actually, maximum run-up heights for the 5 tsunamis herein evaluated are: 5-7 $\mathrm{m}$ at Cumaná for the 1530 event, $5 \mathrm{~m}$ at Barlovento and $3 \mathrm{~m}$ at the Neverí mouth for the 1900 tsunami, $3 \mathrm{~m}$ at western Cumaná for the 1853 and 1929 events and about $1 \mathrm{~m}$ for the 1997 earthquake (Table 1). A difficult aspect to manage, 
though, is the eventual enhancement of the tsunami wave height by contributing underwater sliding, also triggered by the local earthquakes on steep submarine (even subaerial) walls, such as inside the Cariaco Trough, on the continental slope or along steep rocky coasts.

In all the tsunamis analyzed in this paper, eyewitnesses report sea retreat first. That is the case for the 1530, 1853, 1929 and even 1997 tsunamis in western Cumaná (El Salado, El Dique or Puerto Sucre seaport). Testimonies for the latter event were collected by the first author in the first few days following the July $9^{\text {th }}$, 1997 earthquake. Reports of sea oscillations inside the Cariaco Gulf during the 1997 event were also collected. This seems sound in case of the Cariaco 1997 earthquake because the earthquake epicenter was located farther east; more precisely, on the land bridge between the Cariaco and Paria gulfs [Baumbach et al. 2004], the latter gulf lying even farther to the east (Figure 2). The sea surface oscillations detected on western Cumaná during this 1997 earthquake, on the contrary, are attributed to subaerial and submarine slides taking place at the river mouth banks and along the submarine Manzanares Canyon, respectively [Audemard and Leal 2014,2015], as attested by deep turbidite currents in the Cariaco Trough detected by Thunell et al. [1999] and Lorenzoni et al. [2012]. This same argumentation is to be applied to the 1929 earthquake, whose epicenter also lies east of Cumaná, into the Cariaco Gulf, but the tsunami waves occurred on the opposite side of Cumaná, at the Manzanares River mouth (El Salado) predominantly. Instead, a more complex scenario is to be conceived if the 1530 and 1853 earthquakes do actually take place in the deep Cariaco Trough, as proposed by Audemard [1999, 2007], unless the simpler submarine slide hypothesis is accepted for all these tsunamis affecting Cumaná. Aguilar et al. [2016], in order to explain an increase of more open seawater circulation into the Cariaco Gulf, proposes a major change in the Salazar Sill depth (lying just North of northern Cumaná, in the Cariaco Gulf entrance) at around $1853 \mathrm{AD}$, in association to a submarine slide. This could explain the occurrence of inundation of the Caigüire saltflats during this earthquake, which seems not to be reported during other earthquakes and associated tsunamis. But the 1530 tsunami affectation is even more difficult to explain with an earthquake locus in the Cariaco Trough lying due west of Cumaná, taking into account that an Indian village at 2 leagues into the Cariaco Gulf was clearly inundated, with 4 casualties by drowning. Now that run-up height for this 1530 tsunami is better bracketed, numerical modeling of different tsunami scenarios -combining earthquake epi- center west or east of Cumaná, tsunami waves generated by (fully strike-slip or normal oblique) tectonic slip or submarine slide or combination of both-, should provide answers or constraints to this uncertainties. A few first attempts [Audemard et al. 2014], using the piston modeling developed by the Norwegian Geotechnical Institute -NGI-, have been performed, trying to reproduce a $3 \mathrm{~m}$ high inundation at the western coasts of Cumaná. Actually, the Barcelona Embayment shelf configuration with a pure strike-slip motion on EPF, attempting to recreate the 1853 tsunami, induces tsunami waves of only $30 \mathrm{~cm}$ in height [Audemard et al. 2014], which appears insufficient to inundate western Cumaná with $3 \mathrm{~m}$ high waves, unless other local considerations are incorporated (funneling effect of the Manzanares Canyon, riverbore formation, actual oblique -normal-dextral- slip in a pull-apart setting, among others). Very much remains to be done and tested in this field yet.

Speculating about the 1853 slide scenario proposed by Aguilar et al. [2016], which surely inundates Caigüire from the testimonies collected herein, one of their own figures (Figure 15) is much worth discussing. The morphology of the coast and shelf bathymetry at the Cariaco Gulf entrance and just North of Cumaná, and particularly North of Caigüire, points out to a potential large slide that indented the coast at Caigüire and associated shelf; and slid down to deeper waters, as suggested by the belly shape the isobaths exhibit.

In terms of intensity, the ITIS 2012 scale [Lekkas et al. 2013] has been applied to all 5 tsunamis (Table 1). Even for the recent 1997 event, the quantity and quality of the six types of descriptors integrated in the ITIS scale (Quantities, impact on humans, impact on mobile objects, infrastructure, environment and structures) are definitely insufficient for a good well constrained assessment in all cases. However, in some cases, some diagnostic descriptors (e.g., damage to trees, drowned individuals, among others) help to establish the minimum tsunami intensity. In this research, the assessment of the tsunami wave height (or flow depth) by contextualizing the eyewitness account(s) as a whole, has led to more reliable values. In addition, the tsunami descriptions have been also converted into tsunami intensity values by applying ITIS 2012 scale [Lekkas et al. 2013], as well as tsunami magnitude grades by applying Imamura-lida [Iida 1963] scale. This has actually led to more robust and better bracketed tsunami wave heights. However, we need to highlight that although descriptors in the six types of elements assessed in the ITIS 2012 scale appear to have a good level of detail for modern tsunamis, its application to historical tsunamis 


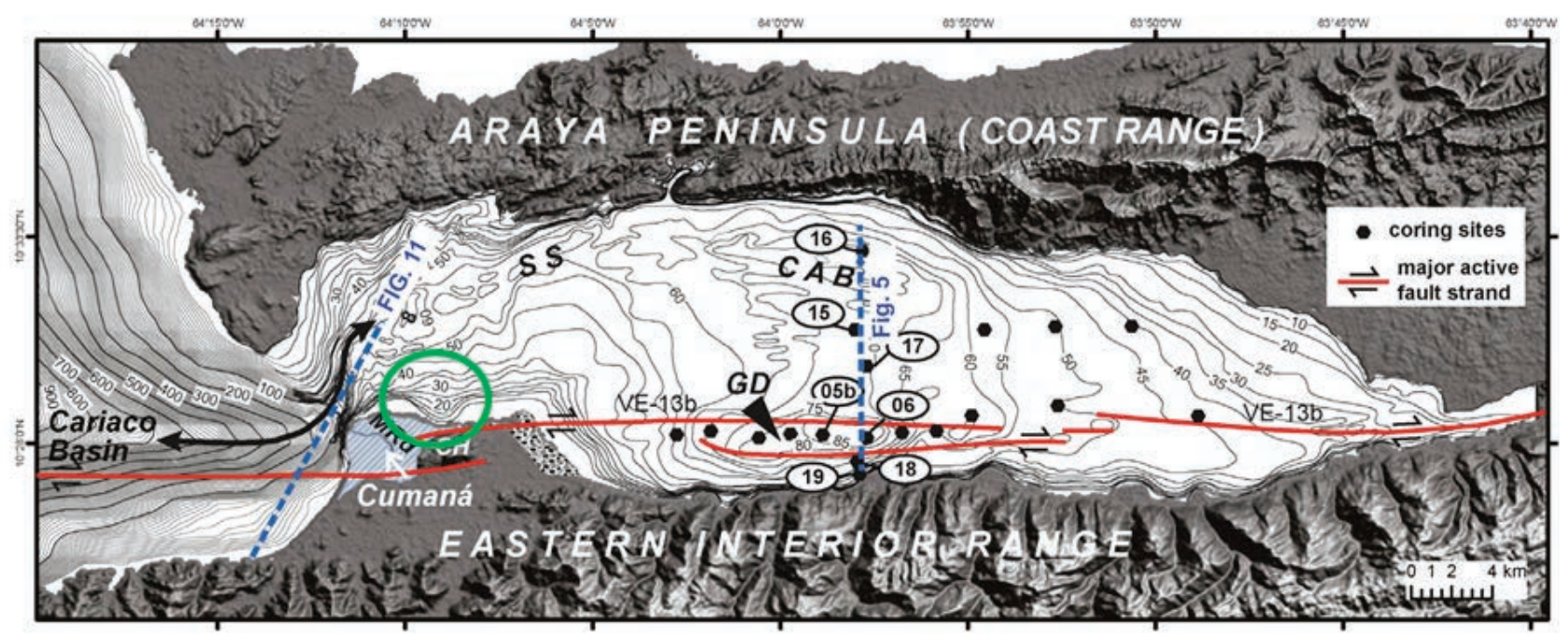

Figure 15. Geomorphic setting of the Cariaco Gulf and of its connection with the Cariaco Basin or Trough. CAB Cerro Abajo Basin; CH: Caigüire Hills; GD: Guaracayal Deep; MRd: Manzanares River delta; SS: Salazar Sill [after Aguilar et al. 2016]. The circle points out the coastal and submarine features that do resemble a large submarine slide, with crown at seashore.

in the modern world characterized by a rather short written history, seems more difficult to implement.

Last but not least, these new estimates on tsunami run-up or wave heights for earthquakes produced by local active tectonics have major implications on search for geologic past tsunami records along the Venezuelan coasts. For the particular case of the Eastern Venezuelan coasts, the search for tsunamites by trenching and coring should be essentially restricted to the first $500-\mathrm{m}$ wide strip from the coastline in low-lying flatlands, if natural (e.g., vegetation, coastal sand barrier height) and anthropogenic (e.g., building and housing, coastal embankments) obstructions to inundation are not significant, due to the modest size of tsunami waves produced by local earthquakes of magnitude up to Mw 7.6, mostly on offshore strike-slip (or normal oblique) faults.

Acknowledgements. This is a contribution to the TERPRO Commission of INQUA, led by Dr. Alessandro Maria Michetti from the University of Insubria (Como, Italy). Funds to the research are provided by FONACIT through grants to Project FONACIT 2013000361 and past projects FONACIT-ECOS Nord PI-2003000090 and PI-2009000818. We wish to thank the funding support the first author received from Istituto Nazionale di Geofisica e Vulcanologia -INGV- and Istituto Superiore per la Protezione e la Ricerca Ambientale-ISPRA- to partly present these results at the VI INQUA International Workshop on Paleoseismology, Active Tectonics and Archaeoseismology (VI PATA) held in Pescina (AQ) between 19 and 24 April 2015, as well as the invitation from the VI PATA Organizing Committee. Really, many thanks for sponsoring me!! It was a very enlightening and an unforgettable meeting in many ways: friendly talks, lively discussions, nice sightseeing, excellent Mediterranean food, eye-filling window geology, lovely re-acquaintances with friends and colleagues, varied wine tasting, teaching fieldtrips (visit to the Fucino 1915 and L'Aquila 2009 surface ruptures and damage to the urban area of l'Aquila itself; and some paleoseismic trenches too!), illuminating Rome archaeoseismic visit, among many others.... It is also a contribution to Working Group 2 of IOCARIBE, the regional subsidiary body of the UNESCO Intergovernmental Oceanographic Commission, which at present is focused on designing, building and implementing the Tsunamis and Other Coastal Hazards Warning System for the Caribbean Sea and Adjacent Regions (CARIBE-EWS). We thank Raquel Vásquez for helping us with some macroseismic data. Last but not least, we are thankful to two anonymous reviewers and the Sector Editor Dr. Francesca Bianco, for providing pertinent comments.

\section{References}

Aggarwal, Y., 1983. Neotectonics of the Southern Caribbean: recent data, new ideas. Acta Científica Venezolana 34(1):17 (Abstract).

Aguilar, I., Beck, C., Audemard, F. A., Develle, A-L., Boussafir, M., Campos C. and Crouzet, C., 2016. Last millennium sedimentation in the Gulf of Cariaco (NE Venezuela): Evidence for morphological changes of gulf entrance and possible relations with large earthquakes. Comptes Rendus Geoscience 348: 70-79.

Altez, R. and Audemard, F. A., 2008. El sismo de 1629 en Cumaná: Aportes para una nueva historia sísmica del oriente venezolano. Boletín Técnico del IMME, UCV, 46(2): 53-71.

Altez, R. and Rodríguez, J. A. (Project Coordinators), 2009. Catálogo Sismológico Venezolano del siglo XX, Fundación Venezolana de Investigaciones Sismológicas, Caracas, 2 vols., 833 pp.

Audemard, F. A., 1999. Nueva percepción de la sismicidad histórica del segmento en tierra de la falla de El Pilar, Venezuela nororiental, a partir de primeros resultados paleosísmicos. VI Congreso Venezolano de Sismología e Ingeniería Sísmica, Mérida, Venezuela (in CD-ROM).

Audemard, F. A., 2002. Ruptura de los grandes sismos históricos venezolanos de los siglos XIX y XX, revelados por la sismicidad instrumental contemporánea. XI Congreso Venezolano de Geofísica, Caracas, Venezuela, Nov. 17-20, 2002 (8pp; Ex- 
tended Abstract in CD-ROM)

Audemard, F. A., 2006. Surface rupture of the Cariaco July 09, 1997 earthquake on the El Pilar fault, northeastern Venezuela. Tectonophysics 424(1-2):19-39.

Audemard, F. A., 2007. Revised seismic history of El Pilar Fault, Northeastern Venezuela, after the Cariaco 1997 Earthquake and from recent preliminary paleoseismic results. Journal of Seismology 11(3): 311-326.

Audemard, F.A., 2011. Multiple trench investigation across the newly ruptured segment of the El Pilar fault in northeastern Venezuela, after the Cariaco 1997 earthquake. In Audemard, F. A., Michetti A. M. And Mccalpin, J. (eds.) Geological criteria for evaluating seismicity revisited: 40 years of paleoseismic investigations and the natural record of past earthquakes, GSA Special papers $\mathrm{N}^{\circ} 479$, Boulder. 133157. doi: 10.1130/2011.2479(06)

Audemard, F.A., 2012. Over 4 decades of paleoseismic studies in Venezuela. How far we have gone and how much still to be done!!!! BELQUA 2012 Annual Scientific Workshop, March 01; The Royal Academies of Belgium for Science and the Arts, Brussels, Belgium. 2 pp (Extended Abstract).

Audemard, F. A., 2014. Evaluación de las amenazas costeras de origen tectónico del noreste de Venezuela por medio de un estudio integrado geológico -geomorfológico, sedimentológico, geocronológico-, geofísico y geodésico. XXVII Reunión de la Asociación Argentina de Geofísicos y Geodestas, San Juan (Provincia de San Juan, Argentina), 10-14/11/2014. 2 pp (Abstract; CD Format).

Audemard, F. A. and Leal, A., 2012. Testimonios históricos de terremotos locales tsunamigénicos en el oriente venezolano VI Jornadas Venezolanas de Sismología Histórica, Caracas, Venezuela, 26 al 28 de marzo de 2012. 2 pp (Abstract).

Audemard, F. A. and Leal, A., 2013. Local tsunamigenic earthquakes in northeastern Venezuela, in the southern Caribbean realm. $8^{\text {th }}$ International Conference on Geomorphology, Paris, Francia, 28-31 agosto 2013 (Abstract).

Audemard, F. A. and Leal, A., 2014. Local tsunamigenic earthquakes off northeastern Venezuela, in the southern Caribbean realm. IASPEI - Regional Assembly Latin American and Caribbean Seismological Commission -LACSC- y III Congreso Latinoamericano de Sismología, Bogotá, Colombia. July 23-25, 2014 (Abstract).

Audemard, F. A. and Leal, A., 2015. Reliability of firsthand accounts on the study of past tsunami events in northeastern Venezuela (southeastern Caribbean
Sea), since 1530 AD. Miscellanea INGV 27, 25-28 (Extended Abstract).

Audemard, F. A., Glimsdal, S. and Leal, A., 2014. Local historical tsunamis along Northeastern Venezuela, Southern Caribbean: tectonic and/or mass wasting induction? First modeling results of strike-slip generation. International Workshop «Mega Earthquakes and Tsunamis in Subduction Zones-Forecasting Approaches and Implications for Hazard Assessment», Rhodes Island, Greece, 6-8 October, 2014 (Abstract). Audemard, F.A., Romero, G., Rendon, H. and Cano, V., 2005. Quaternary fault kinematics and stress tensors along the southern Caribbean from microtectonic data and focal mechanism solutions. Earth-Science Reviews 69(3-4):181-233.

Audemard, F. A., Machette, M. N., Cox, J. W., Dart, R. L. and Haller K. M., 2000. Map and database of Quaternary faults in Venezuela and its offshore regions. U.S. Geological Survey, Open-File Report 00-018.

Audemard, F. A., Beck, C., Moernaut, J., De Rycker, K., De Batist, M., Sánchez, J., González, M., Sánchez, C., Versteeg, W., Malavé, G., Schmitz, M., Van Welden, A., Carrillo, E. and Lemus, A., 2007. La depresión de Guaracayal, estado Sucre, Venezuela: Una cuenca en tracción que funciona como barrera para la propagación de la ruptura cosísmica. Interciencia, 32 (11): 735-741.

Audemard, F. E. and Audemard, F. A., 2002. Structure of the Mérida Andes, Venezuela: relations with the South America-Caribbean geodynamic interaction. Tectonophysics 345 (1-4):299-327.

Baumbach, M., Grosser, H., Romero, G., Rojas, J., Sobiesiak, M. and Welle, W., 2004. Aftershock pattern of the July 9, $1997 \mathrm{Mw}=6.9$ Cariaco earthquake in northeastern Venezuela. Tectonophysics 379:1-23

Beltrán, C. and Giraldo, C. 1989. Aspectos neotectónicos de la región nororiental de Venezuela. Proceedings of VII Congreso Geológico Venezolano, Barquisimeto, 3: 999-1021.

Beltrán C. and Rodríguez J. A., 1995. Ambientes de sedimentación fluvio-deltáica y su influencia en la magnificación de daños por sismos en la ciudad de Cumaná, Proceedings of II Coloquio Internacional de Microzonificación Sísmica, Cumaná, Venezuela (unpublished).

Beltrán, C., Singer, A. and Rodríguez, J. A., 1996. The El Pilar fault active trace (Northeastern Venezuela): neotectonic evidences and paleoseismic data. Proceedings of the $3^{\text {rd }}$ International Symposium on Andean Geodynamics, Saint-Malo, pp 153-156 (Extended Abstract). 
Centeno Graü, M., 1940. Estudios sismológicos. $1^{\circ}$ Edition, Litografía del Comercio, Caracas.

Centeno Graü, M., 1969. Estudios sismológicos. $2^{\circ}$ Edition, Academia de las Ciencias Físicas, Matemáticas y Naturales-ACFIMAN-, Caracas.

Colón, S., Audemard, F. A., Beck, C., Avila, J., De Batist, M., Leal, A. F., Paolini, M. and Van Welden, A., 2015. The $1900 \mathrm{Mw} 7.6$ earthquake offshore North-central Venezuela. Is La Tortuga or San Sebastián the source fault? Journal of Marine and Petroleum Geology 67: 498-511.

Fernández de Oviedo y Valdés, G., 1851. Historia General y Natural de las Indias. Islas y Tierra Firme del Mar Océano. Primera Parte. Imprenta de la Real Academia de la Historia, Madrid. 764 pp.

Funvisis. Instrumental seismicity of Venezuela, period 1910-2013. www.funvisis.gob.ve/sismologia_aplicada.php (last visit on April 23 ${ }^{\text {rd }}$, 2017).

Grases, J., 1990. Terremotos Destructores del Caribe, 1502-1990. UNESCO-RELACIS, Caracas. 132 pp.

Grases, J., Altez, R. and Lugo, M., 1999. Catálogo de sismos sentidos o destructores. Venezuela. 15301998. Academia de Ciencias Físicas, Matemáticas y Naturales -ACFIMAN-/ Facultad de Ingeniería Universidad Central de Venezuela, Editorial Innovación Tecnológica. 654 pp.

Gómez, J. M. 1990. Historia de las fortificaciones de Cumaná. $1^{\circ}$ Edition. Talleres de Impresos Oriente, Cumaná.

González, J., Schmitz, M., Audemard, F. A., Contreras, R., Mocquet, A., Delgado, J. and De Santis, F., 2004. Site effects of the 1997 Cariaco, Venezuela earthquake. Engineering Geology, 72(1-2): 143-177.

Hafeez, H., 2008. Inundation of tsunami waves and its relation to the tsunami runup. Pakistan Journal of Metereology 5(9): 5-10.

Iida, K., 1963. Magnitude, energy and generation mechanisms of tsunamis and a catalogue of earthquakes associated with tsunamis. Proceedings Tsunami Meetings associated with $10^{\text {th }}$ Pacific Sciences Congress, Honolulu, Edited by D.C. Cox, IUGG Monographs 24:7-18.

Jouanne, F., Audemard, F. A., Beck, C., Van Velden, A., Ollarves, R. and Reinoza, C., 2011. Present-day deformation along the El Pilar Fault in Eastern Venezuela: Evidence of creep along a major strikeslip fault. Journal of Geodynamics, 51, 398-410.

Leal Guzmán, A., Vásquez, R., Rodríguez, J. A. y Audemard, F. A., 2017. Análisis macrosísmico del terremoto del 29 de octubre de 1900 en Venezuela. Proceedings XI Congreso Venezolano de Sismología e Ingeniería Sísmica -XI CONVESIS-, 17-
19/07/2017 (Abstract).

Leal, K. and Scremin, L., 2011. Paleotsunamis en el registro geológico de Cumaná, Estado Sucre, Venezuela Oriental. Under-graduate thesis, School of Geology, Mines and Geophysics, Universidad Central de Venezuela. 204 pp +6 appendices

Leal, K., Scremin, L., Audemard, F. A. and Carrillo, E., 2014. Paleotsunamis en el registro geológico de Cumaná, estado Sucre, Venezuela oriental. Boletín Geología UIS 36(2): 45-70.

Lekkas, E. L., Andreadakis, E., Kostaki, I. and Kapourani, E., 2013. A Proposal for a New Integrated Tsunami Intensity Scale (ITIS-2012). Bulletin of the Seismological Society of America, 103(2B): 14931502. doi: $10.1785 / 0120120099$

Lorenzoni, L., Benitez-Nelson, C., Thunell, R., Hollander, D., Varela, R., Astor, Y., Audemard, F.A. and Muller-Karger, F., 2012. Potential role of eventdriven sediment transport on sediment accumulation in the Cariaco Basin, Venezuela. Marine Geology, 307-310: 105-110.

Medina, L., Castañeda, J., Fermín, I., Pérez-Castresana, G. and López-Monroy, F., 2013. Variación espaciotemporal del caudal y el transporte de nutrientes en el río Manzanares. Boletín Instituto Oceanográfico, Venezuela, 52 (2): 67-75.

Minster, J. and Jordan T., 1978. Present-day plate motions. Journal of Geophysical Research, 83:5331-5354.

Mocquet, A., Beltrán, C., Lugo, M., Rodríguez, J. A. and Singer, A., 1996. Seismological interpretation of the Historical data related to the 1929 Cumaná earthquake, Venezuela. $3^{\text {rd }}$ International Symposium on Andean Geodynamics, 203-206 (Extended Abstract).

Mocquet, A., 2007. Analysis and interpretation of the October 21, 1766 earthquake in the Southeastern Caribbean. Journal of Seismology. DOI 10.1007/ s10950-007-9059-x.

Molnar, P., Sykes, L., 1969. Tectonics of the Caribbean and Middle America regions from focal mechanisms and seismicity. Geological Society of America Bulletin 80:1639-1684.

O’loughlin, K. and Lander J., 2003. Caribbean Tsunamis. A 500-Year History from 1498-1998, Kluwer Academic Publishers, The Netherlands. 263 pp.

Oropeza, J. and Audemard, F. A., 2016. Contribución al estudio de tsunamis y otras amenazas costeras en Venezuela. Revista Nuestro Sur: Historia, Memoria y Patrimonio, 9: 193-215.

Oropeza, J., Audemard, F. A.and Beck, C., 2013. Sedimentary record of paleotsunamis on the coastal lagoons of northeastern Venezuela. 14ème Congrès Français de Sédimentologie, ASF-2013 (Abstract). 
Oropeza, J., Audemard, F. A., Beck, C. and Vallée, M., 2015. New potential sedimentary evidences of paleotsunamis on coastal lagoons of Chacopata, State of Sucre, Venezuela. Miscellanea INGV 27, 329-331 (Extended Abstract).

Otte, Enrique, 1977. Las perlas del Caribe: Nueva Cádiz de Cubagua. Fundación John Boulton, Caracas.

Pacheco, J.F. and Sykes, L.R., 1992. Seismic moment catalog of large shallow earthquakes, 1900 to 1989. Bulletin of the Seismological Society of America 82 (3), 1306-1349.

Paige, S., 1930. The Earthquake at Cumaná, Venezuela. January 17, 1929. Bulletin of the Seismological Society of America, 20: 1-10.

Pérez, O. and Aggarwal, Y. 1981. Present-day tectonics of southeastern Caribbean and northeastern Venezuela. Journal of Geophysical Research 86:10791-10805.

Pérez, O., Bilham, R., Bendick, R., Hernández, N., Hoyer, M., Velandia, J., Moncayo, C. and Kozuch, M., 2001. Velocidad relativa entre las placas del Caribe y Sudamérica a partir de observaciones dentro del sistema de posicionamiento global (GPS) en el norte de Venezuela. Interciencia 26(2):69-74.

Reinoza, C., Jouanne, F., Audemard, F. A. And Beck, C., 2015. Geodetic exploration of strain along the El Pilar Fault in Northeastern Venezuela. Journal of Geophysical Research Solid Earth, 120, doi:10.1002/2014JB011483

Rodríguez, L. M., Audemard, F. A. y Rodríguez, J. A., 2006. Casos históricos de licuación de sedimentos inducidos por sismos en Venezuela desde 1530. Revista de la Facultad de Ingeniería, Univ. Central de Venezuela, 21(3): 5-32.

Russo, R.M., Okal, E.A. and Rowley, K. C., 1992. Historical seismicity of the southeastern Caribbean and tectonic implications. Pure \& Applied Geophysics, 139: $87-120$

Schubert, C., 1984. Basin formation along BoconóMorón-El Pilar fault system, Venezuela. Journal of Geophysical Research 89:5711-5718.

Schubert, C., 1987. Depósitos de una gigante hace aproximadamente 1300 años, Puerto Colombia, estado Aragua (Venezuela). Acta Científica Venezolana 38: 509-510.

Singer, A. and Audemard, F. A., 1997. Aportes de FUNVISIS al desarrollo de la geología de fallas activas y de la paleosismología para los estudios de amenaza y riesgo sísmico. In: Grases, J. (ed.): Diseño sismorresistente. Especificaciones y criterios empleados en Venezuela. Publicación Especial Academia de las Ciencias Físicas, Matemáticas y Naturales -ACFI-
MAN-, 33: 25-38.

Singer, A., Lugo, M. and Rojas, C., 1983. Inventario Nacional de Riesgos Geológicos. Informe preliminar. FUNVISIS, 128 pp. + map.

Soulas, J.-P., 1986. Neotectónica y tectónica activa en Venezuela y regiones vecinas. Proceedings of VI Congreso Geológico Venezolano, Caracas 1985, 10: 6639-6656.

Speed, R., Russo, R., Weber, J. and Rowley, K. C., 1991. Evolution of southern Caribbean plate boundary, vicinity of Trinidad and Tobago: discussion. American Association of Petroleum Geologists Bulletin 75(11):1789-1794.

Stephan, J.-F., 1982. Évolution géodinamique du domaine Caraibe, Andes et chaîne Caraibe sur la transversale de Barquisimeto (Vénézuela), Ph.D. thesis, Paris

Thunell, R., Tappa, E., Varela, R., Llano, M., Astor, Y. Müller-Karger, F. and Bohrer, R., 1999. "Increased marine sediment suspension fluxes following an earthquake", Nature 398: 233.

Weber, J. C., Dixon T.H., DeMets C.A., Ambeh, W.B., Jansma, P., Mattioli, G., Saleh, J., Sella. G., Bilham, R. and Pérez, O., 2001. GPS estimate of relative motion between the Caribbean and South American plates, and geologic implications for Trinidad and Venezuela. Geology 29:75-78.

Yanagisawa, H., Koshimura, S., Miyagi, T. and Imamura, F., 2010. Tsunami damage reduction performance of a mangrove forest in Banda Aceh, Indonesia inferred from field data and a numerical model. Journal of Geophysical Research, Vol. 115, C06032, DOI:10.1029/2009jc005587

Yanagisawa, H., Koshimura, S., Goto, K., Miyagi, T,. Imamura, F., Ruangrassamee, A. and Tanavud, C., 2009. The reduction effects of mangrove forest on a tsunami based on field surveys at Pakarang Cape, Thailand and numerical analysis, Estuarine Coastal Shelf Sci., 81: 27-37.

\section{Unpublished primary sources}

Anonymous, Information from Cubagua Island on October 15, 1530. In: Archive of the National Academy of History (ANH), Section Archive Friar Froilán de Rionegro, First settlements on the coast of Cumaná, Shelf 2, Box 1.

Anonymous, 1853. La catástrofe de Cumaná. Un testigo presencial. The National Academy of History, Library, Brochures 1853, F1164.

\section{Newspaper references}

Anonymous, 1853. "Terremoto del 15 de julio en 
Cumaná”. In: Diario de Avisos y Semanario de las Provincias, Caracas: 27 de julio de 1853, p. 2.

Anonymous, 1853. "Más Calamidad en el Oriente". In: Diario de Avisos y Semanario de las Provincias, Caracas: 10 de agosto de 1853, p. 2.

Anonymous, 1853. "Ocurrencias Interiores". In: Diario de Avisos y Semanario de las Provincias, Caracas: 13 de agosto de 1853, p. 2.

Anonymous, 1900. "Estragos del terremoto en Barlovento”. In: La Linterna Mágica, Caracas 2 de noviembre de 1900, p. 2.

Anonymous, 1900. "Notas al susto". In: La Religión, Caracas: 6 de noviembre de 1900, p. 2.

Anonymous, 1929. "Un Trágico Amanecer". In: La Esfera, Caracas: 19 de enero de 1929, p. 1

Anonymous, 1929. "En el Vapor Commewijne. Un relato de la Catástrofe". In: El Nuevo Diario, Caracas: 19 de enero de 1929, p. 3

Anonymous, 1929. "El Terremoto de Cumaná”. In: El Nuevo Diario, Caracas: 22 de enero de 1929, p. 1

Anonymous, 1929. "La Catástrofe de Cumaná". In: El Nuevo Diario, Caracas: 03 de marzo de 1929, p.26

Anonymous, 1929. "Fenomenación Concurrente Durante el Terremoto de Cumaná”. In: El Universal, Caracas: 22 de marzo de 1929, p. 1

Beauperthuy, D., 1853. "Otra relación del terremoto de Cumaná". In: Diario de Avisos y Semanario de las Provincias, Caracas: 10 de septiembre de 1853, p. 2.

Centeno Graü, M., 1900. "Interesantísimo estudio". In: La Linterna Mágica, Caracas: 15 de noviembre de 1900, p. 1.

Espíndola, J. M., 1900. “El terremoto en Los Roques”. In: La Religión, Caracas: 6 de noviembre de 1900, p. 2.

\footnotetext{
*Corresponding author: Franck A. Audemard M, Earth Sciences Dpt., Venezuelan Foundation for Seismological Research -FUNVISIS-, Caracas, Venezuela; email: audemard@funvisis.gob.ve.

(C) 2017 by the Istituto Nazionale di Geofisica e Vulcanologia. All rights reserved.
} 